\title{
Appropriating Women's Thoughts: The Admissibility of Sexual Fantasies and Dreams Under the Consent Exception to Rape Shield Laws
}

Ramona C. Albin*

INTRODUCTION

A woman and her best friend are having coffee. The woman tells her best friend that she fantasized about having sex with one of their classmates. If that classmate subsequently rapes the woman and his defense is that the woman consented to have sex with him, the court could admit evidence concerning the woman's sexual fantasy as evidence of consent. The woman's voiced thought, her fantasy, is not sexual conduct. Nonetheless, the woman's imaginative thought may be considered "sexual behavior," a sexual act, under rape shield laws and is potentially admissible to show her consent. Similarly, if a woman tells her co-worker that she had a dream about having sex with him and a week later he rapes her, her dream-her unconscious thought—is also potentially admissible as evidence of consent. Under current rape shield laws, a woman's thoughts - imagined, or even unconscious - may be appropriated as evidence of consent.

This phenomenon is consistent with rape law reflecting social norms regarding the deviancy of women's sexuality. For example, before the enactment of rape shield laws in the 1970s, rape law rebuked women who were sexually active outside of the marital relationship by allowing evidence of the rape victim's character for non-chastity to show consent or to attack her credibility as a witness. ${ }^{1}$ The justification for allowing

\footnotetext{
* Assistant Professor of Law and Director of Advocacy Programs, Cumberland School of Law, Samford University. Before joining the law school faculty, the author served as an Assistant United States Attorney for the Northern District of Alabama, handling criminal trial and appellate litigation. The author presented an early iteration of this Article at an evidence workshop at the Vanderbilt Law School and is very appreciative of the feedback received from Bennett Capers, Binyamin Blum, Chris Goodman, Jeff Bellin, Julia Simon-Kerr, and Anibal Rosario-Lebron. The author would also like to thank the following individuals for their comments: Olivia Dure, Sandra Hagood, LaJuana Davis, Praveen Krishna, Jeff Anderson, Brannon Denning, and Terrence McCarthy. She also thanks the law students who provided research assistance: Isabel Montoya-Minisee, Stephanie Gushlaw, Elizabeth Pilcher, Ruby Villalobos, Kameron Buckner, and Jack Pouchert. Finally, the author wishes to thank the Cumberland School of Law for a summer research grant that supported work on
} 
such evidence was that unchaste women-women who had sexual relations outside of marriage - violated social norms, were of deficient character, and were more likely to have consented to sex with the defendant or falsely accused the defendant of rape. ${ }^{2}$ Traditional rape law reflected a "normative command that women maintain an ideal of sexual abstinence in order to obtain legal protection"-a "chastity requirement."

While a majority of states limited this character evidence to reputation evidence as to chastity, a minority of states also allowed evidence of "specific prior acts of unchastity." In all jurisdictions, however, in the context of a consent defense, specific acts of unchastity with the defendant were admissible where the defendant raised consent as a defense. ${ }^{5}$ And showing that a victim was unchaste, where the defendant alleged consent, was a complete defense. ${ }^{6}$ Rape trials often devolved into referendums on the victim's character for chastity rather than focusing on the conduct of the defendant. ${ }^{7}$

Today, rape shield laws generally prohibit admission of evidence of the victim's prior sexual behavior and sexual predisposition. ${ }^{8}$ There are exceptions, however, to this general prohibition. Significantly, evidence of the victim's sexual behavior with the defendant may still be

this Article.

1. See Vivian Berger, Man's Trial, Woman's Tribulation: Rape Cases in the Courtroom, 77 Colum. L. Rev. 1, 15-16 (1977) [hereinafter Berger, Man's Trial, Woman's Tribulation] (explaining that courts considered the "victim's character for chastity" as being "pertinent to whether or not she consented to the act that led to the charge of rape" and to "the woman's credibility"); see also Michelle J. Anderson, From Chastity Requirement to Sexuality License: Sexual Consent and a New Rape Shield Law, 70 GeO. WASH. L. REV. 51, 52-53 (2002) ("The law traditionally insisted that the sexual history of a woman who alleged that she was raped was relevant to the truth of her allegation.").

2. Harriett R. Galvin, Shielding Rape Victims in the State and Federal Courts: A Proposal for the Second Decade, 70 MiNN. L. REV. 763, 783-84 (1986).

3. Anderson, supra note 1 , at 53.

4. State ex rel. Pope v. Superior Court, 545 P.2d 946, 950 (Ariz. 1976) (en banc).

5. Galvin, supra note 2, at 785-86.

6. See Norman v. State, 230 S.W. 991, 992 (Tex. Crim. App. 1921) ("The Legislature apparently has selected appropriate language in which to declare that in such a case, the prosecutrix being over 15 years of age when the act was committed, and the proof showing that she was of previous unchaste character, no conviction can result."); see also Galvin, supra note 2, at 766 ("Evidence of previous sexual conduct was deemed relevant at common law on the issue of whether the rape complainant had consented to sexual relations on the occasion in question-a complete defense, if established, to a charge of forcible rape.").

7. Galvin, supra note 2, at 792-93.

8. See FED. R. Evid. 412(a). Rape shield laws allow admission of a woman's sexual history under various exceptions, and the general prohibition is therefore less of a ban than a sieve. Anderson, supra note 1, at 112-13. 
admissible if the defendant claims consent. ${ }^{9}$ This means if the defendant claims that the sexual activity was consensual, then evidence of prior sexual behavior of the victim with the defendant may be admissible, whereas evidence of her sexual predisposition is not. Thus, in the context of a consent defense, not only is the victim's physical conduct with the defendant potentially admissible, but so are her voiced sexual fantasies and dreams about the defendant. ${ }^{10}$ And these sexual fantasies or dreams are potentially admissible even in the absence of any other prior physical conduct with the defendant. ${ }^{11}$

In other words, the same rationale that was the foundation of the chastity requirement applies to the admissibility of women's sexual fantasies and dreams under the consent exception - women who express sexual fantasies act outside social norms, have deficient character, and therefore such evidence is relevant to consent. Essentially, the chastity requirement still applies to women's thoughts. If women voice sexual fantasies or dreams, it evidences her consent, just as women's prior sexual conduct with others was supposedly relevant to consent under traditional rape law. As one commentator noted, "female sexuality that fails to conform to normative standards sits uneasily with rape shield law." 12

Sexual fantasies and dreams, based on imagined or even unconscious thoughts, do not make the fact of consent more or less likely. But, even though such evidence is not relevant to consent, courts have admitted it. ${ }^{13}$ Any arguable relevance is based on unfounded stereotypes of female sexuality, i.e., that women must be mentally and physically chaste, and women who have sexual fantasies "want it" or are somehow deviant. The admissibility of such evidence plays into these stereotypes and may cause unwarranted conclusions based on those stereotypes-a

9. FED. R. EVID. 412(b)(1)(B).

10. This Article focuses on the admissibility of women's sexual fantasies under the consent exception because most victims of sexual assault are women and most perpetrators are men. From 1995 to 2010 , approximately $91 \%$ of rape and sexual assault victims were female and $9 \%$ were male. U.S. Dep'T of Justice, Female Victims of Sexual Violence, 1994-2010, at 3 (2013), https://www.bjs.gov/content/pub/pdf/fvsv9410.pdf [https://perma.cc/SPG2-3ZAK] (citing National Crime Victimization Survey data compiled from 1995-2010). In 2010, 98.1\% of female rape victims reported only male perpetrators. MiCHELE C. BLACK ET AL., NAT'L CTR. FOR INJURY Prevention \& Control, The National intimate Partner and Sexual Violence Survey: 2010 SUMMARY REPORT 24 (2011), http://www.cdc.gov/ViolencePrevention/pdf/NISVS_report 2010-a.pdf [https://perma.cc/23GN-YMQP] [hereinafter NISVS REPORT].

11. See Commonwealth v. Young, 182 S.W.3d 221, 222 (Ky. Ct. App. 2005) (finding admission of the victim's sexual fantasy about the defendant did not violate Kentucky's rape shield rule).

12. Deborah Tuerkheimer, Judging Sex, 97 CORNELl L. Rev. 1461, 1490 (2012).

13. See, e.g., Young, 182 S.W.3d at 222. 
circumstance rape laws were enacted to prevent. ${ }^{14}$ For example, it is well settled that women's rape fantasies are not about a desire to be raped and do not involve wish fulfillment. ${ }^{15}$ Yet, rape fantasies have been admitted as evidence of consent. Such a voiced fantasy fits neatly into unfounded tropes about women's desire to be raped. In a 1952 article published in the Yale Law Journal, the authors, writing anonymously, argued that "a woman's need for sexual satisfaction may lead to the unconscious desire for forceful penetration, the coercion serving neatly to avoid the guilt feelings which might arise after willing participation." 16

The admission of rape fantasy evidence to show consent under current rape shield laws shows that this stereotype is alive and well. ${ }^{17}$ Its admission supports the belief that rape fantasies concern wish fulfillment, rather than an experience for the woman herself. If jurors believe a rape fantasy is wish fulfillment and the defendant claims consent, then the admission of the fantasy has enormous potential to cause unfair prejudice and an unwarranted outcome. At bottom, the admission of such evidence results in the appropriation of women's thoughts to limit legal protection.

This Article examines the admissibility of women's sexual fantasies and dreams under the consent exception, traces its origins, highlights its application, argues that sexual fantasies and dreams should not be admissible under the consent exception, and proposes a practical solution to address this problem.

Part I describes Federal Rule of Evidence 412, the federal rape shield law. Rule 412 prohibits evidence offered to prove that a victim engaged in other sexual behavior or to prove the victim's sexual predisposition. ${ }^{18}$ The Rule contains several exceptions, including the consent exception, which allows the admission of specific instances of the victim's "sexual behavior" with the defendant if the defendant argues consent. ${ }^{19}$ Under the consent exception, the victim's "sexual behavior" may be admissible

14. See Memorandum from Professor Margaret Berger, Reporter, to the Advisory Comm. on Rules of Evidence (May 3, 1993) (on file with the author) [hereinafter Berger, Solutions Memo].

15. See infra Part IV.

16. Forcible and Statutory Rape: An Exploration of the Operation and Objectives of the Consent Standard, 62 YALE L.J. 55, 67 (1952) (footnotes omitted).

17. See People v. Garcia, 179 P.3d 250, 255 (Colo. App. 2007) (“[E]vidence of the victim's alleged rape fantasy, including her statements to defendant concerning the fantasy, is material and relevant, and should have been admitted.").

18. FED. R. EVID. 412(a).

19. FED. R. EVID. 412(b)(1)(B). 
to show consent, but the victim's sexual predisposition is not. ${ }^{20}$ The 1994 Amendment Advisory Committee Notes to Rule 412 defines "sexual behavior" to include actual physical behavior and "activities of the mind, such as fantasies or dreams." 21 On that basis, a women's sexual fantasies and dreams may be admissible to prove consent.

Part II traces the origins of Rule 412 and its amendment in 1994. This section shows that the goal of that amendment, related to the criminal provisions, was to broaden the general prohibition of the rule so that evidence that did not fit neatly into the category of sexual behavior, such as sexual fantasies and dreams, was also excluded. Part III describes cases where state courts have admitted evidence of sexual fantasies to prove consent. Those courts rely, at least in part, on the definition of "sexual behavior" in the 1994 Amendment Advisory Committee Notes to Rule 412.

Part IV argues that sexual fantasies and dreams should be inadmissible under the consent exception for four reasons. First, evidence of a victim's sexual fantasies and dreams are not "behavior" in any meaningful sense and should not be categorized as such. Second, such evidence is not relevant to the issue of consent because a woman's fantasies and dreams, her imaginative or even unconscious thoughts, are not probative of consent. Third, even if arguably relevant, the probative value of such evidence is substantially outweighed by a danger of unfair prejudice. Finally, the admission of sexual fantasies and dreams is contrary to the purpose of rape shield laws. This Article proposes a practical solution to address this problem under the current rule: The Advisory Committee Notes to Rule 412 and courts should categorize evidence of sexual fantasies and dreams as sexual predisposition rather than sexual behavior. This approach would ensure that a victim's thoughts are still excluded by the general prohibition under the Rule, yet not appropriated to show consent - effectuating the intent of rape shield laws.

\section{THE FEDERAL RAPE SHIELD LAW AND “ACTIVITIES OF THE MiND” AS SEXUAL BEHAVIOR}

The federal rape shield law, Federal Rule of Evidence 412, is designed to "safeguard the alleged victim against the invasion of privacy, potential embarrassment and sexual stereotyping that is associated with

20. Id.

21. FED. R. EVID. 412 advisory committee's note to 1994 amendment. 
public disclosure of intimate sexual details and the infusion of sexual innuendo into the factfinding process." 22 In other words, the federal rape shield law was promulgated to protect victim privacy, encourage reporting of sex offenses, and prevent unfair prejudice endangering rational verdicts. The rule currently provides, in relevant part:

Rule 412. Sex-Offense Cases: The Victim's Sexual Behavior or Predisposition

(a) Prohibited Uses. The following evidence is not admissible in a civil or criminal proceeding involving alleged sexual misconduct:

(1) evidence offered to prove that a victim engaged in other sexual behavior; or

(2) evidence offered to prove a victim's sexual predisposition.

\section{(b) Exceptions.}

(1) Criminal Cases. The court may admit the following evidence in a criminal case:

(A) evidence of specific instances of a victim's sexual behavior, if offered to prove that someone other than the defendant was the source of semen, injury, or other physical evidence;

(B) evidence of specific instances of a victim's sexual behavior with respect to the person accused of the sexual misconduct, if offered by the defendant to prove consent or if offered by the prosecutor; and

(C) evidence whose exclusion would violate the defendant's constitutional rights. ${ }^{23}$

Under the general prohibition of Rule 412, as applied to criminal cases involving sexual misconduct, evidence offered to prove that a victim engaged in other "sexual behavior" or evidence offered to prove a victim's "sexual predisposition" is not admissible. ${ }^{24}$ The original rule, enacted in 1978, only prohibited admission of evidence of a victim's past

22. Id.

23. FED. R. Evid. 412(a), (b)(1) (emphasis added). The civil exception to the Rule is not included because this Article focuses on its application to criminal cases.

24. FED. R. EVID. 412(a). 
"sexual behavior." 25 That rule did not include Advisory Committee Notes or a definition of sexual behavior.

In 1994, Congress amended the Rule, expanding the general prohibition to include not only sexual behavior but also sexual predisposition. $^{26}$ Most importantly, the 1994 Amendment Advisory Committee Notes defined "sexual behavior" as "all activities that involve actual physical conduct, i.e. sexual intercourse and sexual contact," or that imply sexual intercourse or sexual contact. ${ }^{27}$ The term "behavior" also includes "activities of the mind, such as fantasies or dreams." 28 Specifically, referencing the general prohibition in Rule 412(a), the Advisory Committee Notes state:

Past sexual behavior connotes all activities that involve actual physical conduct, i.e. sexual intercourse and sexual contact. See, e.g., United States v. Galloway, 937 F.2d 542 (10th Cir. 1991), cert. denied, 113 S. Ct. 418 (1992) (use of contraceptives inadmissible since use implies sexual activity); United States v. One Feather, 702 F.2d 736 (8th Cir. 1983) (birth of an illegitimate child inadmissible); States v. Carmichael, 727 P.2d 918, 925 (Kan. 1986) (evidence of venereal disease inadmissible). In addition, the word "behavior" should be construed to include activities of the mind, such as fantasies or dreams. See 23 C. Wright \& K. Graham, Jr., Federal Practice and Procedure, § 5384 at p. 548 (1980) ("While there may be some doubt under statutes that require 'conduct,' it would seem that the language of Rule 412 is broad enough to encompass the behavior of the mind."). ${ }^{29}$

Because "sexual behavior" includes both physical conduct and sexual fantasies and dreams of the victim, such evidence is generally not admissible under Rule 412.

Unlike "sexual behavior," "sexual predisposition" is not defined in the 1994 Amendment Advisory Committee Notes, nor is sexual predisposition defined elsewhere in the Rules of Evidence. However, the 1994 Amendment Advisory Committee Notes provide some general guidance. The Notes provide that predisposition evidence does not refer to sexual activities or thoughts, but is evidence that "may have a sexual connotation for the factfinder." 30 According to the Notes, "mode of

25. Privacy Protection for Rape Victims Act of 1978, Pub. L. No. 95-540, § 2(a), 92 Stat. 2046, 2046 (1978).

26. Violent Crime Control and Law Enforcement Act of 1994, Pub. L. No. 103-322, § 40141(b), 108 Stat. 1796, 1919 (1994).

27. FED. R. EVID. 412(a) advisory committee's note to 1994 amendment.

28. Id.

29. Id.

30. Id. 
dress, speech, or life-style" would all be barred in criminal cases as evidence of sexual predisposition. ${ }^{31}$ The Notes explain that such evidence should be excluded because its admission would "contravene Rule 412's objectives of shielding the alleged victim from potential embarrassment and safeguarding the victim against stereotypical thinking." ${ }^{32}$ Case law provides little additional guidance regarding the definition of predisposition and primarily relies on the language in the 1994 Amendment Advisory Committee Notes. ${ }^{33}$

But the general prohibition barring evidence of the victim's other sexual behavior or sexual predisposition is not absolute. Rule 412 provides several exceptions, one of which allows the admission of specific acts of a victim's sexual behavior with the defendant where the defendant raises a consent defense. ${ }^{34}$ Under the consent exception, evidence of a victim's "sexual behavior" with the accused may be admissible, but evidence of a victim's sexual predisposition is not. ${ }^{35}$ This is a significant exception because most victims know the perpetrator, and therefore defendants often use consent as a defense. ${ }^{36}$

Because the victim's sexual fantasies and dreams are categorized as "sexual behavior" rather than "sexual predisposition," a victim's sexual

31. Id. Such evidence, however, may be admissible under the constitutional exception. This exception, Federal Rule of Evidence 412(b)(1)(C), allows the trial court to admit evidence in a criminal case where its exclusion would violate the defendant's constitutional rights. FED. R. EvID. 412(b)(1)(C). If the accused can show that exclusion of the evidence, whether sexual behavior or sexual predisposition, would violate his constitutional rights, then that evidence may be admitted. Id. Predisposition evidence may also be admissible under the civil exception to Rule 412(b)(2). FED. R. EVID. 412(b)(2).

32. FED. R. EVID. 412(a) advisory committee's note to 1994 amendment.

33. See Ratts v. Bd. of Cty. Comm'rs, 189 F.R.D. 448, 451 (D. Kan. 1999) (relying on the Advisory Committee Notes for the proposition that "[s]exual predisposition includes evidence that may express a sexual connotation"); see also Glazier v. Fox, No. 2014-106, 2016 WL 827760, at *3 (D.V.I. Mar. 2, 2016) (relying on same passage from the Advisory Committee Notes). Because sexual predisposition may be admissible in civil cases, there is more civil case law on sexual predisposition. Those cases do not define sexual predisposition, however, beyond the general description provided by the 1994 Amendment Advisory Committee Notes.

34. FED. R. EVID. 412(b)(1)(B).

35. Id. This argument assumes that state rape shield laws bar sexual predisposition evidence as well as sexual behavior evidence. Not all do. If they do not, they should, for the same reasons Congress amended Federal Rule of Evidence 412 to add sexual predisposition to the general prohibition.

36. Most victims of rape and sexual assault cases know their attacker. See NISVS REPORT, supra note 10 , at 21 (finding that only $13.8 \%$ of victims reported that a stranger raped them). See also Victims and Perpetrators, NAT'L INST. OF JUSTICE (Oct. 26, 2010), https://www.nij.gov/topics /crime/rape-sexual-violence/Pages/victims-perpetrators.aspx [https://perma.cc/3N3U-CQVP] (citing Bonnie S. Fisher, et al., Bureau of Judicial Statistics, NCJ No. 182369, The Sexual ViCTIMIZATION OF COLLEGE WOMEN 17 (2000), https://www.ncjrs.gov/pdffiles1/nij/182369.pdf [https://perma.cc/6U8T-856X]) ("A study of sexual victimization of college women showed that 9 out of 10 victims knew the person who sexually victimized them."). 
fantasies and dreams may be admissible to prove consent. In fact, the 1994 Amendment Advisory Committee Notes specifically state that a victim's "voiced sexual fantasies involving the accused" may be admissible under the consent exception. ${ }^{37}$

\section{THE History OF THE 1994 AMENDMENT TO THE FEDERAL RAPE SHIELD LAW}

Before Congress promulgated Federal Rule of Evidence 412, states enacted rape shield laws to prohibit the admission of evidence related to a victim's chastity in rape and sexual assault cases. ${ }^{38}$ Michigan passed the first rape shield law in 1974. ${ }^{39}$ By 1976, at least twenty-four states had passed rape shield laws. ${ }^{40}$ There was no federal rule, however, limiting the use of evidence of the victim's past sexual behavior. Such evidence was admissible under Rule 404(a)(2), which allowed the introduction of "evidence of a pertinent trait of character of the victim of the crime offered by an accused." 41 The Advisory Committee Notes to Rule 404(a)(2) provided that "an accused may introduce pertinent evidence of the character of the victim, as in support of a claim of ... consent in a case of rape." ${ }^{42}$ Federal case law provided for the admissibility of specific instances of the victim's prior sexual behavior and reputation and opinion evidence of the victim's character for chastity and circuit courts found reversible error where such evidence was excluded. ${ }^{43}$

37. FED. R. EvID. 412(b) advisory committee's note to 1994 amendment. Relevant to Rule 412(b)(1)(B), the Notes state:

Under the exception in subdivision (b)(1)(B), evidence of specific instances of sexual behavior with respect to the person whose sexual misconduct is alleged is admissible if offered to prove consent, or offered by the prosecution. Admissible pursuant to this exception might be evidence of prior instances of sexual activities between the alleged victim and the accused, as well as statements in which the alleged victim expressed an intent to engage in sexual intercourse with the accused, or voiced sexual fantasies involving that specific accused.

Id.

38. See, e.g., Shand v. State, 672 A.2d 630, 631 (Md. Ct. App. 1996) (giving an overview of Maryland's rape shield statute); see also Privacy of Rape Victims: Hearings on H.R. 14666 and Other Bills Before the Subcomm. on Criminal Justice of the H. Comm. on the Judiciary, 94th Cong. 1 (1976) [hereinafter Hearings] (statement of Rep. William L. Hungate, Chair, Subcomm. on Criminal Justice) ("A number of States have addressed this issue and have modified their laws to make such evidence less easily admissible.").

39. Mich. COMP. LAWS ANN. § 750.520j (West 2019).

40. Hearings, supra note 38, at 2 (statement of Rep. Elizabeth Holtzman).

41. Id. at 1 (statement of Rep. William L. Hungate, Chair, Subcomm. on Criminal Justice).

42. Id.

43. Id. at 4; see also Packineau v. United States, 202 F.2d 681, 687 (8th Cir. 1953) (finding 


\section{A. Introduction of Rule 412}

In 1976, Representative Elizabeth Holtzman sponsored legislation creating Rule 412 "to provide for the protection of the privacy of rape victims." ${ }^{\prime 4}$ During a July 29, 1976, hearing on the legislation, a Deputy Chief of the Criminal Division at the Department of Justice stated that there was no basis in experience to support the premise that an "unchaste" witness is less credible than a "chaste" witness. ${ }^{45} \mathrm{He}$ also rejected the notion that "chastity" has a bearing on consent, and further explained that any marginal relevance of such evidence would be outweighed by the danger of unfair prejudice resulting in an irrational verdict. ${ }^{46}$ As to the scope of the proposed rule, the former National Rape Task Force Coordinator for the National Organization for Women, Mary Ann Largen, testified about the sexual stereotypes surrounding rape prosecutions. ${ }^{47}$ Ms. Largen explained that "[b]ecause the courts confuse rape with healthy sexual union, the victim must also deny any healthy history of, or interest in, sex in order to deny an implication of an 'unconscious desire' to be violated." 48 She also discussed the significant evidentiary hurdles facing rape victims; that is, that rape victims, unlike any other victim, must not simply show that she was raped, but she must also show she did not want to be raped on a conscious or even subconscious level. ${ }^{49}$

On October 28, 1978, Congress passed the Privacy Protection for Rape Victim's Act of $1978,{ }^{50}$ amending the Federal Rules to add protection for rape victims as codified in Rule 412. The Rule provided, in relevant part:

Rule 412. Rape Cases; Relevance of Victim's Past Behavior

(a) Notwithstanding any other provision of law, in a criminal case in which a person is accused of rape or of assault with intent to

\footnotetext{
reversible error where the trial court excluded evidence of the victim's "prior unchaste conduct" with an individual other than the accused), overruled by United States v. Kasto, 584 F.2d 268 (8th Cir. 1978).

44. Hearings, supra note 38, at 2 (statement of Rep. Elizabeth Holtzman).

45. Id. at 4 (statement of Roger A. Pauley, Deputy Chief, Legislation and Special Projects Section, Criminal Division).

46. Id.

47. Id. at 30 .

48. Id. at 31 (statement of Mary Ann Largen, Former N.O.W. Nat'l Rape Task Force Coordinator).

49. Id.

50. Privacy Protection for Rape Victims Act of 1978, Pub. L. No. 95-540, 92 Stat. 2046 (1978).
} 
commit rape, reputation or opinion evidence of the past sexual behavior of an alleged victim of such rape or assault is not admissible.

(b) Notwithstanding any other provision of law, in a criminal case in which a person is accused of rape or of assault with intent to commit rape, evidence of a victim's past sexual behavior other than reputation or opinion evidence is also not admissible, unless such evidence other than reputation or opinion evidence is-

(1) admitted in accordance with subdivisions (c)(1) and (c)(2) and is constitutionally required to be admitted; or

(2) admitted in accordance with subdivision (c) and is evidence of-

(A) past sexual behavior with persons other than the accused, offered by the accused upon the issue of whether the accused was or was not, with respect to the alleged victim, the source of semen or injury; or

(B) past sexual behavior with the accused and is offered by the accused upon the issue of whether the alleged victim consented to the sexual behavior with respect to which rape or assault is alleged. ${ }^{51}$

Rule 412 thus provided that in rape or assault to commit rape cases, reputation or opinion evidence of the victim's past sexual behavior and specific instances of the victim's past sexual behavior was generally inadmissible. ${ }^{52}$ At that time, the federal rape shield law only applied in cases of rape or assault to commit rape, did not apply to other criminal cases or civil cases, and did not define sexual behavior. ${ }^{53}$ Rule 412 also included several exceptions. ${ }^{54}$ Like the current rule, the victim's past sexual behavior with the accused was potentially admissible to show victim consent. $^{55}$

\footnotetext{
51. Id. $\S 2(\mathrm{a})$.

52. See id.

53. Federal Rule of Evidence 412 did not include Advisory Committee Notes when originally

54. Privacy Protection for Rape Victims Act § 2(a).

55. Id.
} enacted. 


\section{B. 1994 Amendment to Rule 412}

In the early 1990s, Congress considered amending Rule 412. The

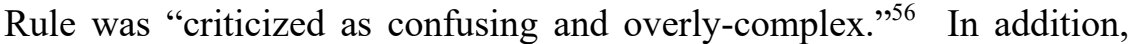
the Rule was criticized as too limited because it did not apply to civil cases. $^{57}$ Concerned that Congress would amend Rule 412 without complying with the Rules Enabling Act and circumvent the Committee on Rules of Practice and Procedure (Standing Committee) of the Judicial Conference, the Standing Committee's Advisory Committee on the Federal Rules of Criminal Procedure began to consider amendments to Rule 412. ${ }^{58}$ This Advisory Committee supported amending Rule 412 and voted to "make it applicable in all civil and criminal cases." Additionally, the Advisory Committee agreed in principle to expand the general prohibition to include evidence offered not only to prove that a victim engaged in other sexual behavior but also evidence offered to prove a victim's sexual predisposition to address the uncertainty created by the term "sexual behavior" and whether a victim's "disposition" would fall within that category. ${ }^{60}$ The consent exception remained substantially the same, allowing evidence of specific instances of the victim's sexual behavior with the accused to prove consent. ${ }^{61}$ The

56. Memorandum from John Rabiej, Chief, Rules Comm. Support Office, Admin. Office of U.S. Courts, to Karen Kremer, Counsel, Legislative \& Pub. Affairs Office 2 (July 8, 1992) (on file with author) [hereinafter Memorandum from John Rabiej].

57. See id. (arguing that because Rule 412's standard differs from Rule 404(a) and only applies in "criminal sexual abuse cases," it is hard to "understand[] the appropriate standards under all the potential permutations created by the interplay of different types of cases, the variety of claims and defenses, and the methods of proving character").

58. Judicial Conference of the U.S., Minutes of the Advisory Committee on Rules of Criminal Procedure 12-13 (May 13-14, 1991), https:/www.uscourts.gov/sites/default/files/fr_import/CR051991-min.pdf [https://perma.cc/8T56-NKDM] [hereinafter Criminal Procedure Advisory Committee Minutes May 13-14, 1991].

59. Judicial Conference of the U.S., Minutes of the Advisory Committee on Rules of Criminal Procedure 5-6 (Nov. 7, 1991), https://www.uscourts.gov/sites/default/files/fr_import/CR11-1991min.pdf [https://perma.cc/3XUN-BQZW]; see also Memorandum from Steve Saltzburg to the Evidence Subcomm. of the Advisory Comm. on Rules of Criminal Procedure 3 (Mar. 8, 1992), https://www.uscourts.gov/sites/default/files/fr_import/CR1992-04.pdf [https://perma.cc/8SR9CGQ5] [hereinafter Memorandum from Steve Saltzburg].

60. Memorandum from John Rabiej, supra note 56, at 2-3. The April 1992 draft by the Evidence Subcommittee of the Advisory Committee on the Federal Rules of Criminal Procedure concerning the consent exception stated: “(a) Evidence of a victim's past sexual behavior or sexual predisposition is not admissible in any civil or criminal proceeding except as provided in subdivision (b)." Id. at 3 .

61. The April 1992 draft by the Evidence Subcommittee of the Advisory Committee on the Federal Rules of Criminal Procedure concerning the consent exception stated: "(b) Evidence of a victim's past sexual behavior or predisposition may be admitted under the following circumstances: ... (2) evidence of specific instances of sexual behavior with the person whose sexual misconduct is alleged if offered to prove consent." $I d$. at 4 . This exception is substantially 
proposed draft amended rule and committee notes by this Advisory Committee do not appear to define sexual behavior or sexual predisposition. ${ }^{62}$

In November 1992, the Civil Rules Advisory Committee to the Standing Committee modified the language adopted by the Advisory Committee on the Federal Rules of Criminal Procedure. ${ }^{63}$ The modified rule still included the general prohibition barring evidence of a victim's past sexual behavior and sexual predisposition, subject to certain exceptions. ${ }^{64}$ This version also included a consent exception allowing "evidence of specific instances of sexual behavior with the person accused of the sexual misconduct, when offered to prove consent by the victim." ${ }^{\text {"6 }}$ The Committee Note also did not include language establishing that sexual behavior under the Rule (and the consent exception) included activities of the mind, such as fantasies or dreams, and did not include language that voiced sexual fantasies by the victim involving the accused may be admissible under the consent exception. ${ }^{66}$

At its December 1992 meeting, the Standing Committee considered the Civil Rules and Criminal Rules Committees' drafts of an amended Rule 412 and blended the two. ${ }^{67}$ The resulting Standing Committee draft contained both (1) the general prohibition language barring evidence of the victim's sexual behavior and sexual predisposition and (2) the consent exception for specific instances of the victim's sexual behavior with the accused. ${ }^{68}$ Importantly, the accompanying Committee Note did not contain any language defining sexual behavior or sexual

the same as the consent exception in the 1978 version, except it removed "past sexual behavior with the accused" under Rule 412(b)(2)(B) and replaced it with "evidence of specific instances of sexual behavior." Additionally, the introductory language to the exception includes sexual behavior and sexual predisposition, but only sexual behavior is referenced in the consent exception under (b)(2).

62. See Memorandum from Steve Saltzburg, supra note 59, at 3-5 (Steve Saltzburg's proposed redraft of Rule 412); id. at 11-15 (attachment of Dave Schlueter's proposed amendment to Rule 412); Memorandum from John Rabiej, supra note 56; Criminal Procedure Advisory Committee Minutes May 13-14, 1991, supra note 58, at 12-14.

63. See Memorandum from Sam C. Pointer, Jr., Chair, Advisory Comm. on Civil Rules, to Hon. Robert E. Keeton, Chair, Comm. on Rules of Practice \& Procedure (Nov. 20, 1992).

64. Judicial Conference of the U.S., Report of THE Advisory COMMitTeE ON CiviL Rules to the Committee on Rules of Practice AND Procedure 5-6 (1992) (on file with author).

65. Id. at 9 .

66. See id.

67. Memorandum from Dave Schlueter, Reporter, to the Advisory Comm. on Criminal Rules (Mar. 15, 1993) (on file with author) [hereinafter Memorandum from Dave Schlueter].

68. Comm. on Rules of Practice \& Procedure of the Judicial Conference of the U.S., Preliminary Draft of Proposed Amendments to the Federal Rules of Evidence, 144 F.R.D. 447, 55963 (1992). 
predisposition. ${ }^{69}$ Because of concern about Congress enacting an amendment to Rule 412 outside of the rules enabling process, the Standing Committee fast-tracked the process of amending Rule 412 and expedited the comment period. ${ }^{70}$ An Advisory Committee on the Rules of Evidence was appointed to hold hearings and spearhead the amendment. $^{71}$

Before the first meeting of the Advisory Committee on the Rules of Evidence, the Advisory Committee Reporter, Professor Margaret Berger, drafted two memorandums for the Committee: one titled "Comments Received with Regard to 412 Amendments" (the "Comments Memo"), ${ }^{72}$ and the other titled "Possible Solutions to Issues Raised with Regard to Rule 412" (the "Solutions Memo"). ${ }^{73}$ In the Comments Memo, Professor Berger addressed public comments asking about the scope of sexual behavior and sexual predisposition covered by the statute and the absence of a definition for predisposition. ${ }^{74}$ Professor Berger explained that sexual thoughts, fantasies, and dreams fit within the category of predisposition, not sexual behavior. ${ }^{75}$ Additionally, Professor Berger noted that such evidence was not sufficiently probative to be admissible. Professor Berger stated:

Although neither the proposed rule nor the Committee Note offer a definition of "predisposition," I suspect that the term was intended to embrace a number of situations that have fit awkwardly, if at all, into the "sexual behavior" requirement. Federal and state courts have considered the admissibility of evidence of sexual thoughts, such as fantasizing, delusions, and dreams, and the admissibility of conduct other than physical sexual acts, such as viewing pornography, working as a topless dancer, nudity, and provocative dressing. The omission of "predisposition" in clause (b)(3), rather than being a drafting oversight, may represent a judgment of the drafters that while predisposition evidence should be excluded because of its potential to embarrass and

69. See id. at 569-77.

70. Judicial Conference of the U.S., Minutes of the Committee on Rules of Practice and Procedure 7-9 (Dec. 17-19, 1992), https://www.uscourts.gov/sites/default/files/fr_import/ST121992-min.pdf [https://perma.cc/U297-KU67] [hereinafter Practice and Procedure Committee Minutes Dec. 17-19, 1992].

71. Judicial Conference of the U.S., Minutes of the Advisory Committee on Rules of Criminal Procedure 12 (Apr. 22-23, 1993) (on file with author); Memorandum from Dave Schlueter, supra note 67.

72. Memorandum from Professor Margaret A. Berger, Reporter, to the Advisory Comm. on Rules of Evidence (May 3, 1993) (on file with author) [hereinafter Berger, Comments Memo].

73. Berger, Solutions Memo, supra note 14. Professor Berger was a faculty member at the Brooklyn Law School.

74. Berger, Comments Memo, supra note 72, at 5-6, 8-11, 20.

75. Id. 
humiliate, its probative value will never be high enough to justify admission. ${ }^{76}$

According to Professor Berger, the predisposition category was intended to cover evidence "offered for the inference that the victim engaged in prior sexual conduct," but did not fall within the category of "sexual misconduct," including evidence such as "dreams, fantasies, partying, [and] watching pornography"-evidence that had insufficient probative value for admission in a criminal sexual assault case. ${ }^{77}$

In the Solutions Memo, Professor Berger explained that predisposition evidence "appeals to sexual stereotyping" and has "so little probative value or indeed relevance that it would never be constitutionally required." ${ }^{, 78}$ The addition of sexual predisposition to the general prohibition of Rule 412 was designed to focus on evidence that did not fit neatly into the definition of sexual behavior and had little probative value but had the potential to invade a woman's privacy and cause unwarranted conclusions. ${ }^{79}$

Professor Berger also recommended that the Advisory Committee should agree on the scope of the rule before addressing definitional issues. ${ }^{80}$ Professor Berger explained that, in a number of state cases, evidence did not clearly constitute "sexual behavior," and therefore was not subject to the general prohibition established by the rule. ${ }^{81}$ She outlined three areas of controversy related to the definition of sexual behavior: (1) fantasies, dreams, and statements in diaries; (2) conduct with a sexual connotation that is not a sexual activity, such as posing for nude photos or watching pornography; and (3) conduct that occurred in public that may have a sexual connotation, such as, dress or partying. ${ }^{82}$ Professor Berger noted that a "sensible definition of 'sexual behavior' coupled with the added ban on 'predisposition' evidence" would cover any evidence falling into these categories. ${ }^{83}$ According to Professor Berger, that approach would not only protect victim privacy, but would

76. Id. at 5-6. Professor Berger responded to a concern that the constitutional exception (at that time Rule 412(b)(3)), which "allow[ed] on constitutional grounds only "evidence of specific instances of sexual behavior," did not include predisposition evidence, such as showing that the alleged victim was a prostitute. $I d$. at 5 .

77. Id. at 20 .

78. Berger, Solutions Memo, supra note 14, at 7.

79. Id. at $1-2$.

80. Id. at 1 .

81. Id.

82. Id.

83. Id. at $1-2$. 
also protect victims "from unwarranted conclusions based on sexual stereotyping" and "encourage victims to come forward when they have been sexually assaulted or harassed." 84 Thus, Professor Berger concluded, if the rule was intended to exclude such evidence to achieve those purposes, then it was unclear whether the rule and commentary provided sufficient definitions of sexual behavior and sexual predisposition. ${ }^{85}$ And the public comments reflected confusion and concern about the meaning of sexual behavior and sexual predisposition. ${ }^{86}$

Professor Berger recommended amending the rule and/or the commentary to address these concerns. Specifically, she suggested adding the following two paragraphs, where the language referencing "activities of the mind" was adopted from Wright and Graham's Federal Practice and Procedure, ${ }^{87}$ to the Committee Note to clarify the breadth of the general prohibition covering sexual behavior and sexual predisposition:

Past sexual behavior connotes all activities that involve actual physical conduct consisting of sexual intercourse or sexual contact or that imply sexual intercourse or sexual contact. See, e.g., United States v. Galloway, 937 F.2d 542 (10th Cir. 1991), cert. denied, 113 S. Ct. 418 (1992) (use of contraceptives inadmissible since use implies sexual activity); United States v. One Feather, 702 F.2d 736 (8th Cir. 1983) (birth of an illegitimate child inadmissible); State v. Charmichael, 727 P.2d 918, 925 (Kan. 1986) (evidence of venereal disease inadmissible). In addition, the word "behavior" should be construed to include activities of the mind, such as fantasies or dreams. See Charles A. Wright \& Kenneth A. Graham, Jr., Federal Practice and Procedure, § 5384 at p. 548 (1980) ("While there may be some doubt under statutes that require 'conduct,' it would seem that the language of Rule 412 is broad enough to encompass behavior of the mind.").

The rule has been amended to also exclude all other evidence relating to an alleged victim of sexual misconduct that is offered to imply a sexual predisposition. This amendment is designed to exclude evidence that does not directly refer to sexual activities or thoughts but that the proponent believes may have a sexual connotation for the fact finder. Admission of such evidence would contravene Rule 412's objective of shielding the alleged victim from potential embarrassment and safeguarding the victim against stereotypical thinking.

84. Id. at 2 .

85. Id.

86. Id.; see also Berger, Comments Memo, supra note 72, at 5-6, 8-11, 17, 20.

87. 23 Charles alan Wright \& Kenneth W. Graham, Jr., Federal Practice and PROCEDURE (1980). 
Consequently, unless the (b)(4) exception is satisfied, evidence such as that relating to the alleged victim's mode of dress, speech, posing in the nude, and life style will not be admissible. ${ }^{88}$

Based on the above draft, White and Graham's conclusion in 1980 that the term "sexual behavior" in the Rule was broad enough to cover "behavior of the mind" formed the apparent justification for characterizing "activities of the mind" as "sexual behavior" in the 1994 Amendment Advisory Committee Notes. ${ }^{89}$ White and Graham, however, categorized "behavior of the mind" as sexual behavior when Rule 412 only included the term "sexual behavior" (the original 1978 version of the Rule).${ }^{90}$ In other words, for Rule 412's general prohibition to cover thoughts in 1980, they had to be considered sexual behavior because categorizing thoughts as sexual predisposition was not an option at that time. Thus, reliance on Wright and Graham as justification for categorizing thoughts as sexual behavior, rather than sexual predisposition, is extremely problematic.

This proposed language was ultimately adopted and included in the 1994 Amendment to the Rule. ${ }^{91}$ The purpose of this language appeared to be to expand the coverage of the general prohibition, whether the evidence fell within "sexual behavior" or "sexual predisposition." Unfortunately, the consequence of including "activities of the mind," such as fantasies or dreams, within the definition of sexual behavior meant that such "activities of the mind" would be admissible as evidence of consent. If sexual fantasies and dreams had been categorized as sexual predisposition, rather than "sexual behavior," then such evidence would be inadmissible under the general prohibition of Rule 412(a) as well as the consent exception of 412(b)(1)(B).

The Advisory Committee on the Rules of Evidence met on May 6 and $7,1993 .{ }^{92}$ The Committee discussed the use of the word

88. Berger, Solutions Memo, supra note 14, at 4. In this iteration of the amended Rule, (b)(4) referenced the civil exception. When Congress amended Rule 412, the civil exception was within (b)(2). See Violent Crime Control and Law Enforcement Act of 1994, Pub. L. No. 103-322, § 40141(b)(2), 108 Stat. 1796, 1919 (Sept. 13, 1994).

89. FED. R. EVID. 412 advisory committee's note to 1994 amendment.

90. See Wright \& GRAHAM, supra note $87, \S 5384$.

91. See FED. R. EvID. 412 advisory committee's note to 1994 amendment.

92. Judicial Conference of the U.S., Minutes of the Advisory Committee on Rules of Evidence 1 (May 6-7, 1993), https://www.uscourts.gov/sites/default/files/fr_import/EV05-1993-min.pdf [https://perma.cc/D2FU-GNBM] [hereinafter Evidence Advisory Committee Minutes May 6-7, 1993]. This committee was under pressure to finalize the draft rule. The chair of the committee informed committee members at this meeting that discussion regarding Rule 412 needed to be completed before the Standing Committee meeting on June 16-17, 1993, because of pending congressional legislation. Id. at 2. See also Practice and Procedure Committee Minutes Dec. 17-19, 
"predisposition" in the general prohibition section. ${ }^{93}$ Some "suggested that 'predisposition' be replaced with evidence offered to show a claimed or asserted 'propensity." "94 Professor Berger explained that she tried to establish "two different categories: sexual behavior involves actual sexual activity whereas predisposition describes evidence that is being offered for a sexual innuendo." 95 The Committee accepted the use of the word predisposition. ${ }^{96}$ The Minutes do not reflect a discussion of the inclusion of "activities of the mind" as sexual behavior in the Committee Note, nor any discussion of the potential impact of such language on the consent exception. ${ }^{97}$

The Standing Committee met in June 1993 and approved the substance of the rule the Advisory Committee on the Rules of Evidence adopted and substantially adopted the proposed committee note. ${ }^{98}$ That approved note included the definitions of sexual behavior and predisposition proposed in the "Solutions Memo," and also included language that voiced sexual fantasies of the victim involving the specific accused may be admissible under the consent exception as sexual behavior of the victim. ${ }^{99}$

Ultimately, Rule 412 was not amended through the rulemaking process because the Supreme Court withheld its approval, not because of the provisions related to criminal cases but because of the application of

1992, supra note 70 , at 8 . Moreover, the minutes of this meeting reflect that the committee determined they would not need to republish the rule, thereby extending the rulemaking process up to another year and a half, unless there were material changes to the rule. Evidence Advisory Committee Minutes May 6-7, 1993, supra, at 5. In other words, there was to be no material changes to the rule that had already been published for comments. The Committee was concerned that Congress would amend the rule in the interim without input from the Judicial Conference. $I d$.

93. Evidence Advisory Committee Minutes May 6-7, 1993, supra note 92, at 5.

94. Id.

95. Id.

96. Id. The minutes reflect that the Committee discussed whether use of predisposition implies that a victim's dress or lifestyle involves sexuality. Id. For that reason, the Committee decided to insert "offered to prove" after evidence to address this issue. Id.

97. There was considerable discussion about the application of the rule to civil cases, the test used in civil cases, whether the consent exception applied in civil cases, and several issues related to the applicability of the rule to civil cases. Specifically, the Committee discussed whether the "consent provision should be expanded to deal with the welcomeness issue in civil sexual harassment cases." Id. at 7 . The Committee ultimately decided that civil and criminal cases needed to be addressed separately under the rule. $I d$.

98. Judicial Conference of the U.S., Minutes of the Committee on Rules of Practice and Procedure 19-20 (June 17-19, 1993), https://www.uscourts.gov/sites/default/files/fr_import/ST061993-min.pdf [https://perma.cc/3AQJ-YG84]. The Standing Committee added language that would allow the prosecutor to admit specific instances of the victim's sexual behavior with the accused when the defendant alleges consent as the defense. Id.

99. Memorandum from J. Ralph K. Winter \& Professor Margaret Berger to the Advisory Comm. on Rules of Evidence, Supp. A (June 22, 1993) (on file with author). 
the rule as drafted to civil cases. ${ }^{100}$ Congress ultimately enacted this formulation of Rule 412 as drafted by the Advisory Committee on Rules of Evidence and the Standing Committee. ${ }^{101}$

Although the amended Rule 412 expanded the types of evidence covered by the general prohibition, the categorization of sexual fantasies and dreams as sexual behavior (rather than predisposition) impacted the reach of the consent exception. The Amendment had the concomitant effect of allowing evidence of a woman's thoughts - evidence that may result in irrational verdicts based on sexual stereotypes - to be admissible in cases involving a consent defense.

\section{COURTS AdMIt SEXUAl FANTASIES AS EVIDENCE OF CONSENT}

Every state has promulgated a rape shield law containing some general prohibition and exceptions to that prohibition, including a consent exception. ${ }^{102}$ State courts have admitted evidence of sexual fantasies by relying on the language in the 1994 Amendment Committee Notes to Rule 412, defining sexual behavior as activities of the mind, including sexual fantasies and dreams. The characterization of women's thoughts as sexual behavior rather than sexual predisposition in Rule 412 impacts the admissibility of women's thoughts in state and federal courts.

For example, in Commonwealth v. Young, the Court of Appeals of Kentucky affirmed a circuit court order admitting a victim's voiced sexual fantasy. ${ }^{103}$ The victim claimed that a police officer "stopped her for a traffic violation and ... coerced her into having sexual intercourse

100. Letter from Chief Justice William H. Rehnquist to John Gerry, Chair of the Exec. Comm. of the Judicial Conference (Apr. 29, 1994) (on file with author).

101. Violent Crime Control and Law Enforcement Act of 1994, Pub. L. No. 103-322, § 40141, 108 Stat. 1796, 1918-19 (Sept. 13, 1994). The Supreme Court withheld approval of the proposed amendment to Rule 412 as applied to civil cases. The Court stated that Rule 412(b) might abridge a civil defendant's substantive rights under Meritor Saving Bank v. Vinson, 477 U.S. 57 (1986). In Meritor, the Court recognized that evidence of an alleged victim's "sexually provocative speech or dress" may be relevant in workplace harassment cases. Id. at 69. The Advisory Committee on Rules of Evidence disagreed with the Supreme Court, explaining that "the proposed rule did not overrule Meritor." Judicial Conference of the U.S., Minutes of the Advisory Committee on Rules of Evidence 2 (May 9-10, 1994), https://www.uscourts.gov/sites/default/files/fr_import/ev5-9.pdf [https://perma.cc/4X6Y-QDZF]. Both houses of Congress amended their bills and used the language drafted by the Advisory Committee on Rules of Evidence. See Judicial Conference of the U.S., Minutes of the Committee on Rules of Practice and Procedure 3 (June 23-24, 1994), https://www.uscourts.gov/sites/default/files/fr_import/ST06-1994-min.pdf [https://perma.cc/5QCML8D5].

102. For a list of state statutes, see 1 BARBARA E. BERGMAN ET AL., WHARTON'S Criminal EVIDENCE $\S 4: 41$ n.39, Westlaw (database updated Nov. 2019).

103. 182 S.W.3d 221, 222 (Ky. Ct. App. 2005). 
with him in lieu of being arrested."104 The officer, Barry Young, was charged with first-degree rape, among other crimes. ${ }^{105}$ The victim was a confidential informant for the police department who eventually reported the rape when she learned that Young planned to visit the county attorney's office while she was there assisting law enforcement in a drug investigation. ${ }^{106}$ Young alleged consensual sex as a defense. ${ }^{107}$

The Kentucky rape shield law, Kentucky Rule of Evidence (KRE) 412, is modeled on Federal Rule of Evidence 412. ${ }^{108}$ Like the federal rule, KRE 412 states that evidence offered to prove the victim engaged in other sexual behavior and evidence offered to prove the victim's sexual predisposition is inadmissible in a case involving sexual misconduct. ${ }^{109}$ KRE 412(b)(1)(B) also provides several exceptions, including an exception for "specific instances of sexual behavior by the alleged victim with respect to the person accused" when the accused claims consent. ${ }^{110}$

Before trial, Young gave notice of his intent to introduce evidence covered by the Kentucky rape shield law. ${ }^{111}$ Among other things, Young sought to introduce evidence that the victim had earlier told her coworker that she had a sexual fantasy about him. ${ }^{112}$ The victim told her co-worker that she wanted to have sex with Young that "would melt the ice in the water cooler" and that she "wanted some of that," referring to Young. ${ }^{113}$

The Commonwealth argued that the victim's alleged behavior before the rape "did not constitute sexual behavior and therefore, would not be admissible under KRE 412(b)(1)(B)." ${ }^{114}$ According to the Commonwealth, that exception only applies "to actual sexual contact between the parties." 115 The Commonwealth argued that the victim's alleged statements were evidence of sexual predisposition, rather than sexual behavior, because the victim "did not act on her wishes at the time," and thus were inadmissible under the exception. ${ }^{116}$ The trial court

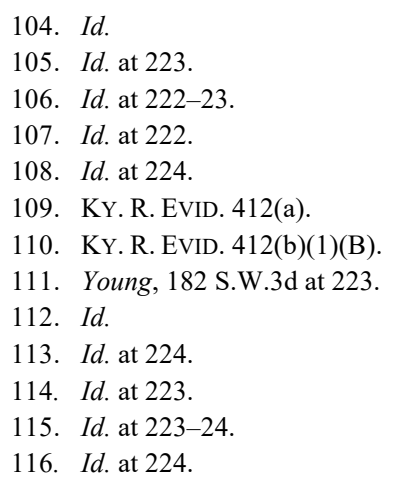


rejected the Commonwealth's argument and ruled that the evidence was admissible. ${ }^{117}$

On interlocutory appeal, the Court of Appeals affirmed the trial court ruling. ${ }^{18}$ Citing the 1994 Amendment Committee Notes to Federal Rule of Evidence 412, the court held that sexual thoughts or fantasies constitute sexual behavior under the rule, rather than sexual predisposition, and are thus admissible under the consent exception. ${ }^{119}$ The court concluded that "[s]ince the prosecuting witness' sexual fantasy was directed toward Young, the trial court properly found that it constituted sexual behavior which is admissible under KRE 412(b)(1)(B)."120 The 1994 Amendment Committee Notes' characterization of sexual fantasies as sexual behavior was determinative in the admission of the victim's alleged sexual fantasy as evidence of consent. ${ }^{121}$ The court therefore found that a victim's sexual fantasy - not even communicated directly to the defendant-was relevant and admissible. ${ }^{122}$

The Colorado Court of Appeals took a similar approach in People $v$. Garcia. $^{123}$ There, the court reversed and remanded for a new trial where the trial court excluded evidence of the victim's alleged rape fantasy. ${ }^{124}$ In Garcia, the victim and the defendant were involved in an intimate relationship for six months (according to the victim) or one year (according to defendant Garcia). ${ }^{125}$ The victim testified that she terminated the relationship at least six months before the sexual assault, while Garcia claimed the parties had consensual sex up to one week before the alleged assault. ${ }^{126}$ Before trial, Garcia filed a "Motion to Introduce Evidence of Prior Sexual Conduct of [the victim]" under the Colorado rape shield law. ${ }^{127}$ The trial court denied the motion, finding the proffered evidence did not fit within an exception to the rape shield law. ${ }^{128}$

At trial, the victim testified that on the date of the sexual assault, she

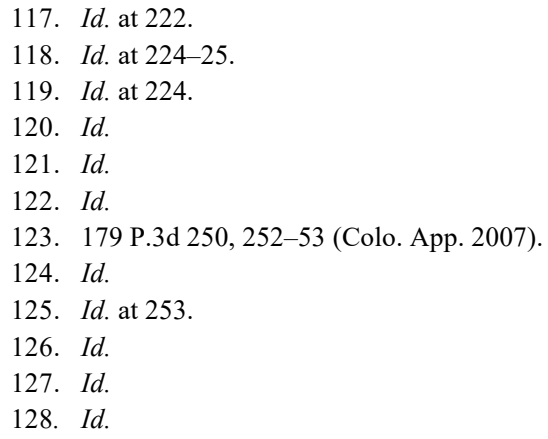


saw Garcia in the hallway of her apartment complex after she put her key in her door lock to enter. ${ }^{129}$ Garcia then turned the key for her and went into the victim's apartment, stating that he just wanted to talk. ${ }^{130}$ After speaking for about fifteen or twenty minutes, Garcia stated, "Well, I guess I'm just going to have to do this." 131 He pulled out a knife, put the knife to the victim's throat, dragged her into the bedroom, threw her on the bed, and bound her hands and feet with tape. ${ }^{132}$ He also forced her to drink liquor and told her that they were "going to have a little party" and then she would watch him die. ${ }^{133}$ He then "cut off her shirt and bra, pressed the knife to her throat, and forced her to perform fellatio."134 Garcia told her he was "going to do what you've not let me do," which the victim interpreted as meaning anal sex. ${ }^{135}$ She was so afraid and upset that she defecated on herself. ${ }^{136}$ After this, Garcia washed her, removed the tape binding her hands and feet, and allowed her to go to the bathroom. ${ }^{137}$ They talked further and Garcia again told the victim he was going to kill himself. ${ }^{138}$ Garcia asked the victim if they could have sex. ${ }^{139}$ The victim ultimately agreed "because of the knife" and Garcia's mental state. ${ }^{140}$ After intercourse, Garcia left and the victim called a friend, who called the police. ${ }^{141}$

Garcia sought to impeach the victim's testimony with an offer of proof that he would testify that he and the victim had prior consensual anal sex, a sexual relationship until one week before the sexual assault, and "[t]he victim had a rape fantasy that they had acted out on numerous occasions." ${ }^{\text {"142 }}$ The trial court ruled that the prior consensual sexual history between the two was irrelevant to Garcia's consent defense. ${ }^{143}$ During cross-examination, the victim stated that she told a detective that Garcia said during the sexual assault, "[R]emember your rape fantasy? 
Well, here it is." ${ }^{144}$ But the victim denied any rape fantasy. ${ }^{145}$

Before Garcia testified, the court advised him that he could not testify about any sexual matters before the date of the sexual assault, including any sexual fantasy of the victim. ${ }^{146}$ Garcia could testify, however, about a sexual fantasy that occurred on the date of the sexual assault. $^{147}$ At trial, Garcia testified that all sexual conduct was consensual and the victim asked him to bind her hands and feet. ${ }^{148}$ When defense counsel tried to introduce evidence that the victim allegedly told Garcia, "[W]e could do it the way I like to do it, my favorite fantasy," and described what that meant, the trial court sustained the state's objection. $^{149}$

The Colorado Court of Appeals held that the trial court erred in excluding Garcia's testimony about his prior sexual relationship with the victim, Garcia's claim that the victim had a rape fantasy that they acted out several times, and the victim's alleged statements about the rape fantasy. ${ }^{150}$ Specifically, regarding the alleged rape fantasy, the court held the alleged statements were material and relevant to Garcia's consent defense, and therefore admissible. ${ }^{151}$ The court reasoned that the victim's alleged statements to Garcia about the rape fantasy was not evidence of sexual conduct under the statute because " $[\mathrm{t}]$ he fantasy could be established without revealing whether the victim had ever acted it out."152 According to the court, the trial court abused its discretion because it improperly applied the rape shield law to this evidence at all. $^{153}$

Curiously, the court relied on the fact that the victim's alleged

\footnotetext{
144. Id. at 254 .

145. Id.

146. Id.

147. Id.

148. Id.

149. Id.

150. Id. at $255-56$.

151. Id. at 255 .

152. Id. (citations omitted). The Colorado Rape Shield Statute provides, in relevant part: Evidence of specific instances of the victim's or a witness's prior or subsequent sexual conduct, opinion evidence of the victim's or a witness's sexual conduct, and reputation evidence of the victim's or a witness's sexual conduct may be admissible only at trial and shall not be admitted in any other proceeding.... At trial, such evidence shall be presumed to be irrelevant except: (a) Evidence of the victim's or witness' [s] prior or subsequent sexual conduct with the actor....

COLO. Rev. STAT. § 18-3-407(1) (2014) (emphasis added). Compare FED. R. Evid. 412 (using the term "sexual behavior" and/or "sexual predisposition"), with COLO. REV. STAT. § 18-3-407(1) (2014) (using the term "sexual conduct").

153. Garcia, 179 P.3d at 255 .
} 
statements concerned thoughts, rather than actions, and the jury would not be prejudiced by statements of the victim's thoughts. ${ }^{154}$ The court stated, "[W]e do not view the victim's statements regarding her fantasy to be unfairly prejudicial. These statements concerned thoughts, not actions. We discern no reason why a jury would be prejudiced against the victim for merely having voiced a fantasy." 155 In other words, according to the court, sexual fantasies are not actions and therefore the jury would not consider such evidence. ${ }^{156}$ Even applying a Colorado Rule of Evidence 403 analysis, the court still admitted the evidence. ${ }^{157}$ Paradoxically, although the majority opinion implied that a fantasy has limited probative value, and therefore the jury would not be prejudiced against the victim for having such thoughts, the majority also found that the victim's fantasies were not only relevant, but also material to Garcia's consent defense. ${ }^{158}$

In a concurring opinion, Judge Bernard agreed with the result but disagreed with the majority's finding that the victim's statements about a rape fantasy were not sexual conduct under the Colorado rape shield statute. ${ }^{159}$ Relying on the language of the statute, precedent, and Federal Rule of Evidence 412, Judge Bernard argued that sexual fantasies fall within the scope of sexual conduct under the Colorado rape shield statute. $^{160}$ Judge Bernard relied on the 1994 Amendment Committee Notes to Rule 412, which state that past sexual behavior included activities of the mind, such as fantasies and dreams. ${ }^{161} \mathrm{He}$ explained the expansive view of sexual conduct was necessary because only then would the general prohibition cover sexual fantasies. ${ }^{162}$

Judge Bernard emphasized the importance of rape shield laws in rejecting dangerous stereotypes regarding female sexuality. ${ }^{163}$ Judge Bernard quoted Wigmore on Evidence, which as recently as 1970 suggested that "[t]he unchaste (let us call it) mentality finds incidental

\footnotetext{
154. Id. at 258 .

155. Id.

156. Id.

157. Id. at 257-58; see also COLO. R. EvID. 403 ("Although relevant, evidence may be excluded if its probative value is substantially outweighed by the danger of unfair prejudice, confusion of the issues, or misleading the jury, or by considerations of undue delay, waste of time, or needless presentation of cumulative evidence.").

158. Garcia, 179 P.3d at 256.

159. Id. at 259 (Bernard, J., specially concurring).

160. Id. at 259 .

161. Id. at 260 .

162. Id. at 261 .

163. Id.
} 
but direct expression in the narration of imaginary sex incidents of which the narrator is the heroine or victim."164 Judge Bernard noted that the Colorado rape shield statute expressly rejected Wigmore's premise that "women accuse men of rape because they have conflated sexual fantasy with criminal violence." $165 \mathrm{He}$ added that evidence of past sexual acts with others is not probative of present consent. ${ }^{166}$ And, according to Judge Bernard, this lack of probity "extends to evidence about a victim's sexual fantasies." 167 Judge Bernard stated, "Requiring a victim to testify about sexual fantasies can be as intrusive as testifying about prior sexual acts." 168 To implement the purpose of the rape shield statute, i.e., to protect a victim's privacy, Judge Bernard would have included sexual fantasies within the scope of sexual conduct, consistent with Federal Rule of Evidence 412. ${ }^{169}$ Judge Bernard quoted Wright and Graham's treatise on Federal Practice and Procedure to explain that even if thoughts are not behavior, "proof of attitudes toward sex can only be viewed as an attempt to prove or insinuate sexual conduct by circumstantial means."

Essentially, Judge Bernard recognized that sexual fantasies do not fit into the definition of "sexual conduct."171 Nonetheless, he concluded that because such evidence involves sexual innuendo, it should be categorized as sexual conduct and excluded under the general prohibition. ${ }^{172}$ If such evidence is characterized as sexual conduct for the general prohibition, however, then it is potentially admissible as evidence of sexual conduct with the defendant. ${ }^{173}$ That is why Judge Bernard joined the majority holding that the victim's sexual fantasies should not be excluded under the consent exception. ${ }^{174}$

Young and Garcia show that courts need clarity regarding the admissibility of women's sexual fantasies and dreams under rape shield laws. In both cases, the courts admitted evidence of women's thoughts

\footnotetext{
164. Id. (quoting 3A JOHN HENRY WigmoRe, EVidenCE IN TRIALS AT COMMON LAW § 924A (James H. Chadbourn ed., 3d ed. 1970)).

165. Id.

166. Id. (citing People v. McKenna, 585 P.2d 275, 278 (Colo. 1978) (en banc)).

167. Id.

168. Id.

169. Id.

170. Id. (quoting WRIGHT \& GRAHAM, supra note $87, \S 5384$ ).

171. See id.

172. See id.

173. Id. at 262; see also COLO. REV. STAT. § 18-3-407(1)(a) (2014) (providing an exception for "[e]vidence of the victim's or witness' prior or subsequent sexual conduct with the actor").

174. Garcia, 179 P.3d at 262 (Bernard, J., specially concurring).
} 
to prove consent even when that evidence had little to no probative value. In Young, the court admitted evidence of a sexual fantasy that the victim never communicated directly to Young. ${ }^{175}$ In Garcia, the court admitted evidence of an alleged rape fantasy (that the victim denied) that occurred long before Garcia raped the victim. ${ }^{176}$ The admission of such evidence subjects the victim to the intrusion on her privacy that rape shield laws were enacted to prevent and relies on sexual stereotypes related to women's sexual fantasies.

\section{THE RATIONALE FOR EXCLUSION AND A PROPOSAL FOR CHANGE}

Under Rule 412, sexual fantasies and dreams are "sexual behavior" that may be admissible to prove consent. ${ }^{177}$ That approach fails to fully implement the purpose of the rule and undermines policies underlying rape shield laws. In order to exclude such evidence under the current paradigm, sexual fantasies and dreams should be categorized as sexual predisposition, not sexual behavior, and barred under the consent exception. First, sexual fantasies and dreams do not fit within the category of sexual behavior. Sexual fantasies and dreams are thoughts, not actual sexual conduct. Second, as previously explained, the legislative history supports this view. ${ }^{178}$ The predisposition ban was meant to address this type of evidence-evidence that the proponent believes may have a sexual connotation for the factfinder. Third, sexual fantasies and dreams are not even relevant to consent and therefore the categorization as sexual predisposition evidence does not unfairly impact the defendant. Fourth, even if relevant, the probative value is substantially outweighed by a danger of unfair prejudice. Finally, the admission of such evidence is contrary to the purpose of rape shield laws. Its admission invades the victim's privacy, is rife with sexual innuendo, appeals to sexual stereotypes, and has the potential to cause unwarranted outcomes.

\section{A. Fantasies and Dreams Are Not Behavior}

First, as a threshold matter, sexual fantasies and dreams are not behavior and, therefore, the definition in the 1994 Amendment

175. Commonwealth v. Young, 182 S.W.3d 221, 224 (Ky. Ct. App. 2005).

176. Garcia, 179 P.3d at 255 .

177. FED. R. EVID. 412(b); see also FED. R. EVID. 412 advisory committee's note to 1994 amendment.

178. See discussion infra Section II.B. 
Committee Notes should be changed to reflect that fact. The first entry in the Oxford English Dictionary defines behavior as the "[m]anner of conducting oneself in the external relations of life." 179 Behavior involves external actions, and thoughts involve "activities of the mind." The Merriam-Webster dictionary defines behavior as: (1) "the way in which someone conducts oneself or behaves"; 2(a) "the manner of conducting oneself"; and 2(b) "anything that an organism does involving action and a response to stimulation." 180

The mainspring of sexual behavior is actual physical acts. ${ }^{181}$ State courts similarly define sexual behavior as physical acts involving sexual intercourse, sexual contact, or an attempt to engage in such acts. ${ }^{182}$ State courts have held that sexual behavior includes written or verbal descriptions of past sexual activity, ${ }^{183}$ and a federal court held that a victim's statement propositioning an investigating police officer by asking him if he wanted to crawl into bed with her qualified as sexual behavior under Rule 412, and was excluded on that basis. ${ }^{184}$

Unlike sexual acts or propositions, fantasies and dreams involve an individual's internal life and are, by definition, imagined, even if voiced. The Merriam-Webster dictionary defines fantasy as "the free play of creative imagination" or "a creation of the imaginative faculty whether

179. Behavior, OXFORD ENGLISH DICTIONARY (2d ed. 1989).

180. Behavior, MERRIAM-WEBSTER DICTIONARY, https://www.merriam-webster.com/dictionary /behavior [https://perma.cc/AT42-5CGQ] (last visited Jan. 25, 2020).

181. See FED. R. EVID. 412(a) advisory committee's note to 1994 amendment ("Past sexual behavior connotes all activities that involve physical conduct, i.e. sexual intercourse and sexual contact." (citations omitted)).

182. See, e.g., State v. Alberts, 722 N.W.2d 402, 408 (Iowa 2006) ("We are unable to conclude that posing nude is per se, sexual conduct.... [P] osing nude does not infer or connote sexual activity or conduct." (quoting State v. Zaehringer, 280 N.W.2d 416, 420 (Iowa 1979))); State v. Wright, 776 P.2d 1294, 1298 (Or. Ct. App. 1989) (““[P]ast sexual behavior' means a volitional or non-volitional physical act that the victim has performed for the purpose of the sexual stimulation or gratification of either the victim or another person or an act that is sexual intercourse, deviate sexual intercourse or sexual contact, or an attempt to engage in such an act, between the victim and another person.").

183. See, e.g., State v. Fowler, 200 P.3d 591, 593-95, 597 (Or. Ct. App. 2009) (holding that the victim's diary entries where she described her sexual activities with individuals other than the defendant constituted sexual behavior and was inadmissible under Oregon's rape shield law); Violett v. Commonwealth, 907 S.W.2d 773, 776 (Ky. 1995) (affirming the trial court's exclusion of letters the victim wrote to her boyfriend describing her sexual activities with him as sexual behavior covered by the general rape shield prohibition).

184. United States v. Papakee, 573 F.3d 569, 572-73 (8th Cir. 2009). Regardless, there is a distinction between a verbalized intent to engage in sex with the accused directed at the accused at or near the time of the rape or sexual assault versus a victim relating a fantasy or dream about having sex with the accused. The former expresses a conscious desire (although not determinative or conclusive of consent) and the latter, is, by definition, based on creative imagination or even unconscious thought. 
expressed or merely conceived." 185 The American Heritage Dictionary of the English Language defines fantasy as "[t]he creative imagination." 186 The Penguin Dictionary of Psychology defines fantasy as "the mental process of imagining objects, symbols, or events not immediately present." 187 And, social science researchers in the area of sexual fantasies define them as "acts of imagination." 188 In a study of more than 23,000 sexual fantasies, a researcher and clinician found that sexual fantasies are "extensions of our capacity for creativity . . putting us on a more even keel psychologically."189

Dreams are not even the object of the conscious mind. The American Heritage Dictionary of the English Language defines dreams as "[a] series of images, ideas, emotions, and sensations occurring involuntarily in the mind during certain stages of sleep," 190 as does Webster's New World Medical Dictionary. ${ }^{191}$ Sleep researchers characterize dreams as "perceptual expression and dramatization of the dreamer's thoughts," which "seem to be self-governing and out of our control." 192 Fantasies and dreams are not, in any meaningful sense, "behavior."

\section{B. The History of Federal Rule of Evidence 412 Establishes That the Predisposition Ban Was Meant to Encompass Sexual Fantasies and Dreams.}

Second, the history of the 1994 amendment to Rule 412 supports categorizing sexual fantasies and dreams as sexual predisposition rather than sexual behavior. It shows that the rationale for adding sexual predisposition to the general prohibition was to bar evidence that fit awkwardly, if at all, into the sexual behavior category, such as evidence

185. Fantasy, MERRIAM-WEBSTER DiCTIONARY, https://www.merriam-webster.com/dictionary/ behavior [https://perma.cc/L22L-KP8S] (last visited Jan. 25, 2020).

186. Fantasy, THE AMERICAN Heritage DiCTIONARY OF THE EngLish LANGUAGE, https://www.ahdictionary.com/word/search.html?q=fantasy [https://perma.cc/A8AX-AEHE] (last visited Jan. 25, 2020).

187. Fantasy, The PENGUIN Dictionary OF PSYCHOLOGY (4th ed. 2009).

188. Jenny Bivona \& Joseph Critelli, The Nature of Women's Rape Fantasies: An Analysis of Prevalence, Frequency, and Contents, 46 J. SEX RES. 33, 33 (2009) [hereinafter Bivona \& Critelli, The Nature of Women's Rape Fantasies].

189. Brett Kahr, Who's Been Sleeping in Your Head: The Secret World of Sexual FANTASIES 376 (2009).

190. Dream, The American Heritage Dictionary of the English Language (5th ed. 2015).

191. Dream, WeBster's New WORLD MEDICAL DiCTIONARY, https://ahdictionary.com/word/ search.html?q=dream [https://perma.cc/6RSJ-NJFJ] (last visited Jan. 25, 2020).

192. William H. MOORCROFT, UNDERSTANDING SLEEP AND DREAMING 153 (2d ed. 2013). 
of sexual thoughts, dreams, and fantasies. ${ }^{193}$ Sexual fantasies and dreams are the type of evidence the predisposition ban was meant to prohibit. Professor Berger explained at the Committee's only meeting on amending Rule 412 that the Rule established two categories: (1) sexual behavior, which involves "actual sexual activity," and (2) sexual predisposition, which involves "sexual innuendo."194 Fantasies and dreams do not involve actual sexual activity, and may not even involve sexual innuendo, but may be susceptible to such an interpretation. Thus, evidence of fantasies and dreams fits more comfortably within the confines of sexual predisposition evidence.

Evidence characterized as sexual predisposition evidence, however, may not represent actual sexual predisposition. Professor Berger noted that the addition of "predisposition" within the rule was to cover evidence being "offered for the inference that the victim engaged in prior sexual conduct." 195 And the Advisory Committee Notes explain that the predisposition exclusion is meant "to exclude evidence that does not directly refer to sexual activities or thoughts but that the proponent believes may have a sexual connotation for the factfinder." ${ }^{\text {"196 }}$ For example, the Note describes dress as evidence covered under the predisposition category. ${ }^{197}$ Dress does not connote a sexual predisposition, but it may have a sexual connotation for the fact-finder. For this reason, such evidence is excluded under the rule. Similarly, sexual fantasies and dreams do not represent a sexual predisposition, but such evidence may have a sexual connotation for the factfinder. ${ }^{198}$

\section{Sexual Fantasies and Dreams Are Not Relevant to Consent}

Third, the exclusion of such evidence does not unfairly prejudice the defendant because it is not relevant to consent. ${ }^{199}$ Under Federal Rule of

\footnotetext{
193. Berger, Comments Memo, supra note 72, at 5-6.

194. Evidence Advisory Committee Minutes May 6-7, 1993, supra note 92, at 5.

195. Berger, Comments Memo, supra note 72, at 20.

196. FED. R. EVID. 412(a) advisory committee's note to 1994 amendment.

197. Id.

198. The categorization of evidence as sexual predisposition evidence or sexual behavior evidence under Rule 412 is problematic. The sexual predisposition category contains evidencesuch as dress, fantasies and dreams, or lifestyle - that does not show sexual predisposition. However, categorizing sexual fantasies and dreams as predisposition evidence in the Advisory Committee's Note may accomplish the goal, consistent with the purpose of the rule, of excluding this type of evidence in criminal cases under the current paradigm.

199. The exclusion of victim's sexual fantasies and dreams would not violate the Confrontation Clause. Rape shield laws have been upheld against Sixth Amendment claims. See, e.g., United States v. A.S., 939 F.3d 1063, 1073 (10th Cir. 2019) (explaining that "the class of cases in which
} 
Evidence 402, only relevant evidence is admissible. ${ }^{200}$ Under Rule 401, "[e]vidence is relevant if: (a) it has any tendency to make a fact more or less probable than it would be without the evidence; and (b) the fact is of consequence in determining the action."201 An expression of imagined thoughts, not based in reality, and, in some cases even unconscious, does not make the fact of consent more or less likely. Fantasies about sex with the defendant does not make it more likely that the victim actually agreed to have sex with the defendant on a particular occasion. Women's dreams do not suggest real-life consent.

Social science research on women's sexual fantasies supports this conclusion. In a study of male and female sexual fantasies, researchers concluded that women's fantasies of dominance and submission were not correlated with actual sexual attitudes. ${ }^{202}$ In other words, there is not an

evidence otherwise barred by the rape shield statute has been deemed to be constitutionally compelled is restricted to those which demonstrate a theory of witness bias or motive to lie" and holding that the defendant's theory did not fall within that limited constitutional exception (quoting Rosanna Cavallaro, Rape Shield Evidence and the Hierarchy of Impeachment, 56 AM. CRIM. L. REV. 295, 299 (2019))). See also United States v. Lockhart, 844 F.3d 501, 510-11 (5th Cir. 2016) (rejecting the defendant's Confrontation Clause claim based on the district court's exclusion of evidence of the victim's prior- and post-indictment acts of prostitution under Rule 412 finding that the exclusion did not abridge defendant's ability to present a defense). The purpose of the exclusion, in addition to protecting victim privacy and encouraging reporting of sexual assault, is to exclude evidence that is not relevant and may result in unwarranted verdicts based on sexual stereotypes. For instance, in United States v. Never Misses a Shot, the Fifth Circuit rejected the defendant's claim that the district court's exclusion of evidence under Rule 412 of the victim's prior molestation by another perpetrator violated his constitutional rights under the Confrontation Clause. 781 F.3d 1017, 1029 (8th Cir. 2015). The court found that Confrontation Clause rights are limited and the limitations include "concerns about harassment, prejudice, confusion of the issues, the witness' safety or interrogation that is repetitive or only marginally relevant." Id. (quoting United States v. Pumpkin Seed, 572 F.3d 552, 560 (8th Cir. 2009)). Evidence that is not relevant cannot implicate the Sixth Amendment. Further, the Sixth Amendment is not implicated if the probative value of evidence is substantially outweighed by a danger of unfair prejudice. See United States v. Torres, 937 F.2d 1469, 1473 (9th Cir. 1991) (finding an incident that occurred approximately six months after alleged sexual abuse was not relevant, and, therefore, the Confrontation Clause did not mandate that defendant be allowed to cross-examine witness about the incident; evidence was not admissible under the exception to the rape shield rule that would render evidence of past sexual behavior admissible if evidence was constitutionally required). See also Richmond v. Embry, 122 F.3d 866, 872 (10th Cir. 1997) ("[L]egitimate state interests behind a rape shield statute such as giving rape victims heightened protection against 'surprise, harassment, and unnecessary invasions of privacy' may allow the exclusion of relevant evidence if the state's interest in excluding the evidence outweigh the defendant's interests in having the evidence admitted." (quoting Michigan v. Lucas, 500 U.S. $145,150(1991)))$.

200. FED. R. EVID. 402.

201. FED. R. EVID. 401

202. Eileen L. Zurbriggen \& Megan R. Yost, Power, Desire, and Pleasure in Sexual Fantasies, 41 J. Sex Res. 288, 295 (2004). The study concluded that male sexual fantasies of dominance were correlated with rape myth acceptance, and because attitudes such as rape myth acceptance have been found to be correlated with aggressive sexual behavior, these fantasies may be associated with "victim-blaming attitudes about rape." Id. at 297-98. The authors note that further research is 
association between women's sexual fantasies and behavior. The authors conclude that "women us[e] fantasy as a safe space to focus on their own desire and pleasure."203 Because women's sexual fantasies are not correlated to behavior, such evidence cannot make a fact of consequence more or less likely.

Research into women's rape fantasies further supports the argument that sexual fantasy evidence is not probative of consent. First, there is scientific consensus that "mental imagery of realistic violent rape is almost never an erotic experience and that nearly all women have no interest in acting out a realistic fantasy of rape." 204 Second, research into women's aversive rape fantasies - for example, where the fantasizer is resistant throughout the fantasy, where the fantasizer's character in the fantasy is attacked while in a vulnerable position, where the fantasizer describes the fantasy as at a minimum as unpleasant - shows that these fantasies generally generate "feelings such as guilt, shame, and embarrassment." "205 Rather than involving wish fulfillment, the authors concluded that aversive rape fantasies "operate as attempts to deal with the fear of actual rape by gaining some sense of control over rape situations and rehearsing how one might deal with actual rape."206 Aversive rape fantasies do not represent a woman's desire to be raped; rather, they are attempts to deal with the trauma of rape.

The admissibility of a woman's rape fantasy as evidence of consent is grounded in the view that a rape fantasy is evidence that a woman wants to be raped and that the rape fantasy involves wish fulfillment. Empirical data does not support this view, as women who experience rape fantasies are no more likely to be raped than other women. ${ }^{207}$ And, as discussed above, there is scientific consensus that "nearly all women have no interest in acting out a realistic fantasy of rape." 208 The stereotype of a rape fantasy as wish fulfillment ignores that the fantasy is a powerful experience on its own, and does not involve the desire to actually be raped or to consent to sex in a rape fantasy paradigm. Women's rape fantasies do not involve wish fulfillment, are not relevant to consent, and should be excluded.

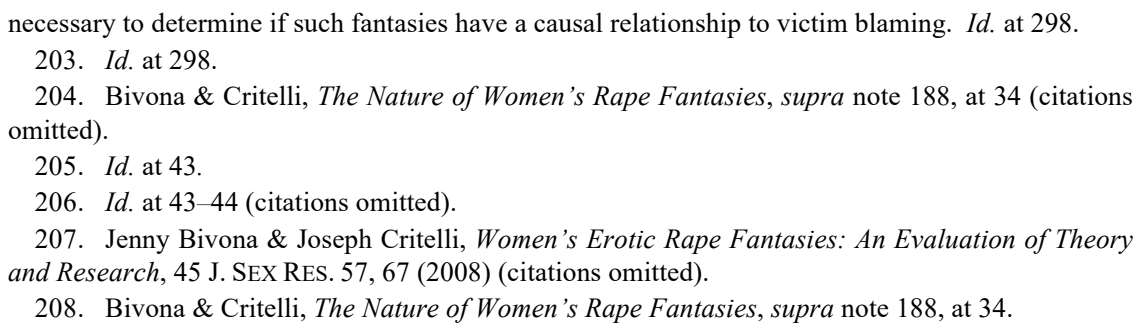




\section{The Admission of Fantasies and Dreams as Evidence of Consent Is Unfairly Prejudicial and May Cause Unwarranted Outcomes}

Fourth, even if evidence of sexual fantasies and dreams were arguably relevant, its limited probative value is far outweighed by the danger of unfair prejudice. The admission of such evidence creates the real danger of unfair prejudice because of extant stereotypes of women's rape fantasies as wish fulfillment. Based on these stereotypes the jury could infer that because the woman had a sexual or rape fantasy, she wanted to be raped or consented to the perpetrator's actions, thus causing an unwarranted outcome based on social stereotypes - the precise harm that rape shield laws aimed to prevent.

Under Federal Rule of Evidence 403, a court may exclude relevant evidence if its probative value is substantially outweighed by a danger of unfair prejudice. ${ }^{209}$ In Old Chief v. United States, the Supreme Court defined "unfair prejudice," as applied to a criminal defendant, as "an undue tendency to suggest decision on an improper basis, commonly, though not necessarily, an emotional one." 210 The Court explained that "[s]uch improper grounds certainly include... generalizing a defendant's earlier bad act into bad character and taking that as raising the odds that he did the later bad act not now charged."211 Although Old Chief addresses unfair prejudice in the context of a defendant and references prior bad acts, the same principle is applicable here. The admission of a woman's sexual fantasies and dreams to prove consent generalizes her expression of sexual fantasy as evidence that she "wants it" or of wish fulfillment, raising the odds that she consented to sex with the defendant. This suggests a decision on an improper basis and is the type of unfair prejudice the Court warned against.

\section{People v. Jovanovic}

Young and Garcia show the danger of unfair prejudice generated by the admission of women's sexual fantasies. ${ }^{212}$ Those state appellate courts found evidence of sexual fantasies material and relevant even though they had little or no probative value. ${ }^{213}$ The courts generalized

\footnotetext{
209. FED. R. EVID. 403.

210. 519 U.S. 172, 180 (1997) (quoting FED. R. EVID. 403 advisory committee's note).

211. Id.

212. See Commonwealth v. Young, 182 S.W.3d 221 (Ky. Ct. App. 2005); Colorado v. Garcia, 179 P.3d 250 (Colo. App. 2007); see also infra Part III.

213. Young, 182 S.W.3d at 224-25; Garcia, 179 P.3d at 257-58.
} 
the victims' fantasies as raising the odds that she consented. ${ }^{214}$ Similarly, in People v. Jovanovic, a New York appellate court found the victim's fantasies and prior non-normative sexual activity relevant to consent, even though the victim's prior sexual conduct fell squarely within the confines of the rape shield law. ${ }^{215}$ These cases reflect the unfair prejudice generated by women's sexual activity and sexual fantasies that fall outside normative standards.

In Jovanovic, the court reversed a trial court's exclusion of statements in four emails from the victim to the defendant concerning her fantasies about snuff films and comments that "evinced or implied some degree of interest in sadomasochism." 216 It is important to note that Jovanovic does not involve sexual fantasies of the victim that involve the defendant. ${ }^{217}$ The excluded emails concern prior sexual conduct of the victim with another individual involving Bondage and Discipline, Dominance and Submission, Sadism and Masochism (BDSM), sexual conduct of other individuals (not the defendant or the victim), and statements that show the victim had an interest in BDSM with others. ${ }^{218}$ Not one of the contested statements concerned a fantasy involving the defendant or actual sexual conduct between the victim and the defendant. Not one statement expressed her desire to have actual sexual conduct with the defendant. Nevertheless, the appellate court found the evidence relevant to consent on the ground that the messages were meant to convey "her interest in exploring the subject of such activities with him."219 Jovanovic demonstrates the danger of unfair prejudice and unwarranted outcomes resulting from sexual stereotypes regarding women's sexual fantasies or what is considered non-normative sexual conduct. Because the victim evidenced an interest in BDSM generally, the appellate court concluded that the jury could infer she was interested in BDSM with the defendant, even though her emails at issue on appeal did not express that interest. ${ }^{220}$

Jovanovic was charged with kidnapping, sexual abuse, and sexual assault. ${ }^{221}$ According to the victim's testimony at trial, she and Jovanovic communicated by email beginning in the summer of 1996 and

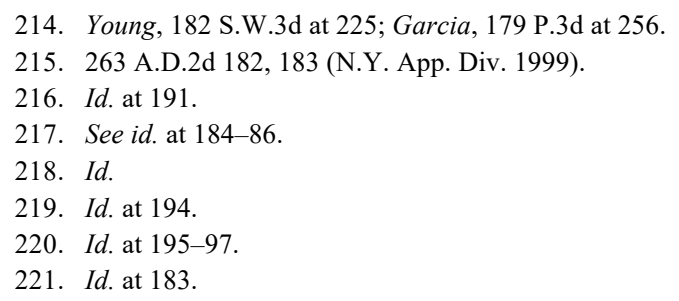


decided to meet for the first time the evening of November 22. ${ }^{222}$ They went out to dinner and planned to see a movie after eating. ${ }^{223}$ After dinner, however, Jovanovic asked the victim "if she wanted to see a video at his apartment." 224 The victim testified that she told Jovanovic, "I don't know," because she did not want to but struggled being assertive. $^{225}$ Nonetheless, the victim and Jovanovic went back to his apartment, and watched a video where "Muppet-like characters" had sex and were violent. ${ }^{226}$ Jovanovic served the victim some tea that the victim said had a "chemical taste" to it. ${ }^{227}$ During the movie, "Jovanovic left the room and returned with some strips of fabric." 228 After the movie ended, Jovanovic ordered her, in a stern voice, to take her shirt and pants off and then he tied her arms and legs to a futon using the strips of cloth. ${ }^{229}$ The victim said "she did not protest because she did not know what to think." 230 He then began pouring hot candle wax onto her stomach. $^{231}$ She told him to stop and demanded that he untie her. ${ }^{232} \mathrm{He}$ then pulled her panties off, dripped wax on her vaginal area, and poured wax on her nipples. ${ }^{233}$ At one point he gagged her, blindfolded her, and then bit her nipples and collarbone. ${ }^{234}$ After about an hour, he carried her to his bedroom and the victim said, "[D]on't rape me, don't dismember me, don't kill me." ${ }^{235}$ At one point, he tied her up so that she was on her stomach and her feet were tied up behind her. ${ }^{236}$ He then "penetrated her rectum with either a baton or his penis, causing the complainant intense pain." 237 She woke up at some point on November 23, still tied up. ${ }^{238}$ He untied her, but she subsequently tried to escape, so Jovanovic "tied her up again." ${ }^{239}$ Later that evening, she was able to escape, although he

\footnotetext{
222. Id. at $184-86$.

223. Id. at $186-87$.

224. Id. at 187 .

225. Id.

226. Id.

227. Id.

228. Id.

229. Id.

230. Id.

231. Id. at 188 .

232. Id.

233. Id.

234. Id.

235. Id.

236. Id.

237. Id.

238. Id.

239. Id.
} 
fought to restrain her. ${ }^{240}$ The victim rode the subway to her dormitory, received a call from her friend Luke, went to his apartment, and told him Jovanovic tied her up, sodomized her with a stick, hit her with a baton, and burned her. ${ }^{241}$

The defendant asserted a consent defense. ${ }^{242}$ He sought admission of emails to show the victim's state of mind regarding consent and his own state of mind regarding the victim's intentions. ${ }^{243}$ The appeal centered on four emails where the trial court required redactions under the rape shield law. ${ }^{244}$ The trial court admitted numerous emails between the victim and the defendant. The victim and Jovanovic met over the internet in the summer of $1996 .{ }^{245}$ Jovanovic told the victim, an undergraduate student at Barnard, that "he studied molecular genetics and computational biology at Columbia."246 In their first online conversation, Jovanovic stated his "interest in the grotesque, the bizarre, and the occult," and talked about a photographer who used corpses in his pictures. ${ }^{247}$ The victim mentioned "her interest in snuff films (i.e., films in which a person is killed).,"248

In October 1996, the victim and Jovanovic exchanged emails where she raised the subject of pagan rituals, snuff films, and asked how tall he was. $^{249}$ On November 10, Jovanovic responded to her question about how tall he was, asking: "As for my height, why? Are you looking to be dismembered by a tall, dark stranger, or something of that sort? I'm sometimes strange and dark, but of average height, so perhaps you should look elsewhere." 250 The victim responded and wrote about the Columbia tunnels, their appropriateness for a snuff film, and "asked if he had any ideas for murder plots." 251 Jovanovic responded with an email about the true story of a man who killed a woman in October 1996 he met in person after their online conversations. ${ }^{252}$ On November 13 and 14 , Jovanovic and the victim continued emailing back and forth about

\footnotetext{
240. Id. at $188-89$.

241. Id. at 189 .

242. Id. at 183 .

243. Id.

244. See id. at 189-92.

245. Id. at 184 .

246. Id.

247. Id.

248. Id.

249. Id. at $184-85$.

250. Id. at 185 .

251. Id.

252. Id.
} 
"fantasies for snuff films, and the [victim's] purported interest in what she termed 'a tall dark dismember-er." ${ }^{253}$ All the aforementioned email evidence was admitted at trial. ${ }^{254}$ Four emails from November 18, 19, and 20 were redacted, ${ }^{255}$ and on appeal, the court held that the redactions were a reversible error that "improperly hampered defendant's ability to present a defense." 256

a. Redaction \#1 - One sentence from November 18 email that references another woman's unrelated rape claim

On November 17, the victim emailed the defendant about having taken a woman she knew, Karen, to the emergency room after the woman told the victim that she was raped the previous evening and the victim told Jovanovic how upset she was. ${ }^{257}$ Jovanovic responded, emailed her his phone number, and asked if the victim wanted to call him. ${ }^{258}$ She replied to the email by asking if this was "a plot to begin dismemberment." 259 On November 18, the victim explained to Jovanovic her relationship with Karen. ${ }^{260}$ The victim told Jovanovic that she had a prior intimate relationship with Luke, Karen's ex-boyfriend. ${ }^{261}$ The victim also stated that Karen warned her to stay away from Luke. ${ }^{262}$ In her email to Jovanovic, the victim described Luke as "attached to one skitzophrenic [sic] stalker X-intrest [sic] d'amour."263

The trial court ordered only one sentence deleted from that email. ${ }^{264}$ The sentence read, "So said intrest [sic] plotted my death as well as a means of getting attention, thus the rape," 265 referencing Karen. The victim did not reference any claim of rape that she made; rather, she described activity by Luke's ex-girlfriend. ${ }^{266}$ Nothing in the email references the victim's relationship to the defendant, nor does she make

\footnotetext{
253. Id.

254. Id. at 184 .

255. Id. at 189-92.

256. Id. at 183 .

257. Id. at 185-86.

258. Id. at 185 .

259. Id.

260. Id.

261. Id. at 185-86.

262. Id. at 186 .

263. Id. at 185 .

264. Id. at 190 .

265. Id.

266. See id.
} 
any statements about the defendant. ${ }^{267}$

b. Redaction \#2 - Several paragraphs from November 19 email describing the victim's prior sexual relationship with Luke, Luke's sexual assault when he was in high school, and another sexual experience of Luke's

Jovanovic requested more details about the victim's relationship with Luke. $^{268}$ On November 19, the victim sent Jovanovic an email describing her relationship with Luke and her interactions with Karen. ${ }^{269}$ The trial court redacted several paragraphs from this email where the victim briefly recounted that Luke previously seduced her. ${ }^{270}$ She stated, "[S]o he seduced me. [C]ome to Ufm, I did[,] come to my apartment, I did[,] then he got me,",271 and gave a description of a sexual assault upon Luke that occurred when Luke was in high school. ${ }^{272}$ She also described an experience Luke had with his old boyfriend and a dominatrix. ${ }^{273}$ Here, the email either references Luke's past sexual relationships or the victim's past relationship with Luke. Nothing in this email references anything about the defendant.

c. Redaction \#3 - One phrase from November 19 email and one sentence from November 20 email stating that Luke "got her" (referencing the victim's earlier sexual relationship with Luke) and where the victim relates Luke was a sadomasochist in their past sexual relationship and she was his slave

Jovanovic responded, again on November 19, "Then he got you? How suspenseful." 274 The trial court redacted the words, "[t]hen he got you." 275 The trial court also redacted a portion of the victim's response on November 20 where the victim replied, "No duh, there's more, more interesting than sex, yes he did catch me, no sex, but he was a sadomasochist and now I'm his slave and its [sic] painful, but the fun of telling my friends 'hey I'm a sadomasochist' more than outweighs the

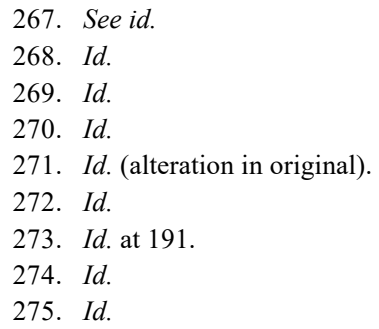


torment." 276 The trial court did not exclude portions of the November 20 email where the victim asked about snuff films and where she speaks of the taboos surrounding the questions she wants to ask. ${ }^{277}$ In the email she stated, "I think you may just be toying with the idea of dismemberment." 278 She also stated she had to "push herself, see how far she can take it" and added, "It could get sick. And just may." 279 Here, again, the redacted language has nothing to do with the victim and Jovanovic's relationship. It only discloses the victim and Luke's prior sadomasochistic relationship.

d. Redaction \#4 - One sentence from November 20 email where the victim states that she is at times a "pushy bottom" (submissive)

Jovanovic responded to her November 20 email and asked if she was submissive at times. ${ }^{280}$ The trial court redacted the following from her response: "[A]nd yes, I'm what those happy pain fiends at the Vault call a "pushy bottom." 281 The victim did not express her desire to enter into a sadomasochistic relationship with Jovanovic, and the victim and Jovanovic did not discuss the parameters of any sexual relationship.

The trial court found the redacted portions of the emails were inadmissible under New York's rape shield law because "they constituted evidence of the [victim's] prior sexual conduct, having the effect of demonstrating her "unchastity.",282 The trial court also precluded the defense from questioning the victim or Luke about "whether the two had mutually engaged in consensual sadomasochism."283 Finally, although Jovanovic was permitted to ask Luke whether he caused the victim's bruise visible on November 24, he was barred from asking "whether Luke's own conduct toward the [victim] at any prior time had caused any bruising." 284

The appeals court rejected the trial court's analysis and held that the New York rape shield law did not support excluding the redacted

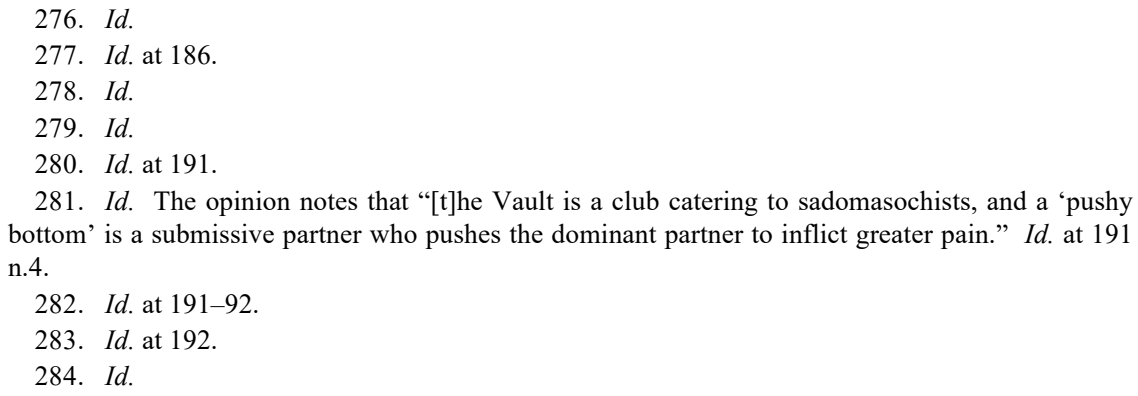


statements and precluding the proposed questions. ${ }^{285}$ The court found that the redacted email messages were not subject to the protections of the rape shield law "because they did not constitute evidence of the sexual conduct of the complainant. Rather, they were merely evidence of statements made by the complainant about herself to Jovanovic." 286 The court drew a "distinction between evidence of prior sexual conduct and evidence of statements concerning past or contemplated sexual conduct." 287 The court reasoned that evidence of sexual conduct "would generally be introduced (if admissible) as a basis to infer that she had voluntarily behaved in such a way on prior occasions with others," ${ }^{288}$ and therefore more likely behaved the same way in the case at trial. But a statement about sexual conduct "is frequently relevant not to prove the truth of the matter stated, but rather, for the fact that the speaker made the statement. That is, a statement may be relevant as proof of the speaker's, or listener's, state of mind." ${ }^{289}$ Specifically addressing the victim's statements here, the court found:

[T] he [victim's] statements to Jovanovic regarding sadomasochism were not necessarily offered to prove the truth of what she said, i.e. that she actually was a sadomasochist. Rather, much of their importance lay in the fact that she chose to say these things to Jovanovic in the context of her electronic, on-line conversation with him, so as to convey to him another message, namely, her interest in exploring the subject of such activities with him. ${ }^{290}$

Thus, because the victim evinced an interest in BDSM in the past and defined herself as submissive, the court concluded that she was interested in a sexual relationship with Jovanovic. ${ }^{291}$

The court conflates a hearsay analysis with a rape shield analysis, apparently finding the evidence relevant and admissible because, according to the court, the statements go to the victim's state of mind and are not allegedly offered for their truth. ${ }^{292}$ This analysis fails to address rape shield issues. The statements, even if offered to show her state of mind, are also offered to show her sexual tendency toward sadomasochism. This would allow the jury to infer, based on prior

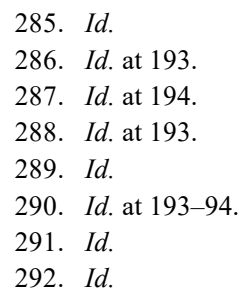


sexual conduct with other individuals and not the defendant, that she consented to sex with the defendant. In fact, the court concluded that the redactions limited the victim from being fully cross-examined about statements that imply her interest in sadomasochism. ${ }^{293}$ Even though the court noted that rape shield laws reject the premise that the character of a woman for chastity is probative or relevant to consent, ${ }^{294}$ the admission of emails describing her prior sexual conduct or professed predisposition to sadomasochism is admitted precisely for that purpose, i.e., because she professed some interest in sadomasochism. ${ }^{295}$

The redacted emails discuss the victim's sexual conduct with others, sexual conduct of others, or non-sexual actions she took related to others. This evidence fits squarely within the protections of the rape shield law. For example, the first redacted email references Luke's ex-girlfriend's rape allegation. ${ }^{296}$ The second redacted email describes the victim's prior sexual relationship with another person, Luke's sexual assault when he was in high school, and Luke's prior sexual history. ${ }^{297}$ The third redacted email explicitly addressed the victim's interaction with Luke where she alleged both she and Luke were sadomasochists. ${ }^{298}$ The redaction in the fourth email ("and yes, I'm what those happy pain fiends at the Vault call a "pushy bottom"') addresses the victim's role as a submissive. ${ }^{299}$ In the email, the victim neither stated she wanted to be Jovanovic's pushy bottom, asked about having sex with Jovanovic, nor consented to sex with Jovanovic. ${ }^{300}$

The appellate court's holding and rationale here appear to reflect judgments about women's sexuality and non-normative sexual behavior and the danger of relying on sexual stereotypes. According to the court, the redacted email statements should have been admitted because the statements convey a message to the defendant- " the subject of such activities with him." 301 In other words, because the victim's emails included statements about a past sadomasochistic relationship and that she was a submissive, there was probative evidence that she consented to such activities with the defendant. Because the

293. Id. at 191.

294. Id a 192 (quoting 1 John Henry Wigmore, A Treatise on the ANGlo-American SYSTEM OF EVIDENCE IN TRIALS AT COMMON LAW $§ 62$ (3d ed. 1940)).

295. See id. at 183.

296. Id. at 186.

297. Id. at 190-91.

298. Id. at 191.

299. Id.

300. See id.

301. Id. at 194. 
victim engaged in such sexual conduct outside the mainstream in the past, the jury could infer her consent to such sexual activity with the defendant.

Recognizing the weakness in the initial rationale for admitting the redacted emails, the court offered as an alternative rationale that the redacted statements fall within exceptions to the rape shield law. ${ }^{302}$ First, the court found that the statements should be viewed as prior sexual conduct with Jovanovic because the statements were so intimate and, "[v]iewed with the purpose of her statements in mind," should not have been excluded. ${ }^{303}$ According to the court, a "history of intimacies generally "bolster[s] a claim of consent." 304 But Jovanovic and the victim did not have a history of intimate sexual contact or conduct; they met for the first time the night of the sexual assault. ${ }^{305}$

Second, the court concluded that the evidence would be admissible under the interests of justice exception. ${ }^{306}$ The defense did not seek to introduce the evidence to show the victim's "unchastity"; rather, the evidence was "relevant to establish that she purposefully conveyed to Jovanovic an interest in engaging in consensual sadomasochism with him."307 Under this rationale, any victim who discusses other sexual activity with an alleged perpetrator evidences an interest in engaging in sexual activities with the perpetrator. But none of the redacted emails describe her desire to engage in such conduct with Jovanovic. ${ }^{308}$

More importantly, the court's finding that the victim's past BDSM activity or her statement that she has been called a "pushy-bottom" is evidence of consent worthy of cross-examining the victim shows the danger of the admission of this type of evidence. If the court arrived at an unwarranted conclusion based on sexual stereotypes, so could the

\footnotetext{
302. Id. at 195 .

303. Id. at 196 .

304. Id. (quoting Berger, Man's Trial, Woman's Tribulation, supra note 1, at 58).

305. See id. at $184-87$.

306. Id. at 197.

307. Id.

308. The court's rationale evidences a complete lack of understanding of the centrality of actual consent in a BDSM relationship. The defining characteristic of BDSM is explicit consent. "Although BDSM comprises vast and varied activities, the explicit informed consent of all those involved represents the most prevalent characteristic of BDSM." Cara R. Dunkley \& Lori A. Brotto, The Role of Consent in the Context of BDSM, SEXUAL ABUSE (forthcoming) (manuscript at 4). And, explicit consent relates to all stages of the BDSM interaction: "Consent represents an ongoing interactive and dynamic process that entails several precautionary measures, including negotiations of play, open communication of desires and boundaries, mutually defining terms, the notion of responsibility and transparency, and ensuring protection from harm through competence and skill." Id. at 5 .
} 
jury. According to the court, the emails, which showed that the victim had a "master-slave" relationship with another individual, that the victim was interested in BDSM, and that she was submissive, would "have permitted Jovanovic to effectively place the [victim] in a somewhat less innocent, and possibly more realistic, light." ${ }^{309}$ In other words, because she was involved in previous sadomasochistic relationships, she was more likely to have consented to the conduct of the defendant here. Because a woman expressed interest or experience with a nonmainstream sexual activity with individuals other than the perpetrator, the court admitted evidence of that activity so that the jury can infer consent. That is the admission of prior sexual conduct with other individuals to show that the victim acted in conformity therewith and contravenes the entire purpose of the rape shield laws.

The holdings in Garcia, Young, and Jovanovic illustrate the danger of unfair prejudice and unwarranted outcomes based on the admission of women's sexual fantasies or dreams or any non-mainstream sexual activity - the same danger that propelled the enactment of Federal Rule of Evidence 412. In 1976, at a congressional hearing on Rule 412, a Deputy Chief in the Criminal Division at the Department of Justice testified regarding the admissibility of sexual conduct of a victim:

[W]hatever marginal relevance such evidence may possess to show the likelihood of the complainant's consent to a subsequent act of sex is considerably outweighed by the public interest in preventing unfair prejudice at trial so as to endanger the chances of obtaining a rational verdict based on the totality of evidence, as well as protecting the privacy of the victim and combatting the well documented reluctance of victims of forcible sex offenses to report such incidents because of fear that their reputations and private lives will be unduly exposed to the "unfeeling scrutiny of the courtroom.",310

This quote is as applicable to the admission of sexual fantasies and dreams as it was to prior sexual conduct of the victim. The admission of the victim's sexual fantasies or dreams not only invades the victim's privacy, but it also endangers the chances of obtaining a rational verdict.

309. Jovanovic, 263 A.D.2d at 201.

310. Hearings, supra note 38, at 4 (statement of Roger A. Pauley, Deputy Chief, Legislation \& Special Projects Section, Criminal Division) (quoting James J. Wesolowski, Note, Indicia of Consent? A Proposal for Change to the Common Law Rule Admitting Evidence of Rape Victim's Character of Chastity, 7 LOY. U. CHI. L.J. 118, 124 (1976)). 


\section{E. Admission of Sexual Fantasies and Dreams as Evidence of Consent Is Contrary to the Purpose of Rape Shield Laws}

Finally, the purpose of rape shield laws is to "safeguard the alleged victim against the invasion of privacy, potential embarrassment and sexual stereotyping that is associated with public disclosure of intimate sexual details and the infusion of sexual innuendo into the factfinding process." ${ }^{311}$ The admission of sexual fantasies and dreams as evidence of consent contravenes each of these objectives. First, exposing a victim's thoughts, or her unconscious dreams, invades her private internal life. As Judge Bernard explained in Garcia, "[r] equiring a victim to testify about sexual fantasies can be as intrusive as testifying about prior sexual acts." 312 Second, as noted earlier, fantasies are the function of creative imagination and dreams are unconscious thoughts. Being compelled to disclose information that is not even based in reality, thoughts an individual would not contemplate disclosing in open court, does not safeguard the victim. Third, as shown above, such disclosure infuses sexual stereotypes and innuendo into the trial process, potentially causing unwarranted outcomes. The admission of such evidence contravenes the purpose of rape shield laws.

\section{F. Fantasies and Dreams as Sexual Predisposition}

In order to exclude the victim's sexual fantasies or dreams from admission under the consent exception, the 1994 Amendment Advisory Committee Notes to Rule 412 needs to change. Specifically, the definition of sexual behavior should not include "activities of the mind, such as fantasies or dreams," and that language (and the accompanying cite to Wright and Graham's Federal Practice and Procedure) $)^{313}$ should be excised from that portion of the Notes. Additionally, in subdivision (b) of the Notes, which characterizes "voiced sexual fantasies involving the specific accused" as an example of the type of specific instances of conduct of the accused that would be admissible under the consent exception, ${ }^{314}$ should also be excised.

In order to ensure that the victim's sexual fantasies or dreams are covered under the general prohibition of Rule 412, the definition of sexual predisposition in the Notes should include "thoughts, such as

311. FED. R. EVID. 412 advisory committee's note to 1994 amendment.

312. People v. Garcia, 179 P.3d 250, 261 (Colo. App. 2007) (Bernard, J., specially concurring).

313. FED. R. EVID. 412 advisory committee's note to 1994 amendment.

314. Id. 
fantasies or dreams." That portion of the Notes should read:

The rule has been amended to also exclude all other evidence relating to an alleged victim of sexual misconduct that is offered to prove a sexual predisposition. This amendment is designed to exclude evidence that does not directly refer to sexual activities or thoughts but that the proponent believes may have a sexual connotation for the factfinder. Admission of such evidence would contravene Rule 412's objectives of shielding the alleged victim from potential embarrassment and safeguarding the victim against stereotypical thinking. Consequently, unless the (b)(2) exception is satisfied [the civil exception], evidence such as that relating to the alleged victim's mode of dress, speech, or lifestyle, or thoughts, such as fantasies or dreams, will not be admissible. ${ }^{315}$

This change to the Advisory Committee Notes would directly impact federal rape shield law. Although not binding, federal courts have relied on the Notes to interpret the Rules of Evidence. In terms of state rape shield laws, courts have relied, at least in part, on the 1994 Amendment Advisory Committee Notes to justify admission of sexual fantasies. The categorization of sexual fantasies and dreams as sexual predisposition rather than sexual behavior no longer allows state courts to rely on the federal rules to justify admission of such evidence, and will hopefully spur states to amend their statutes to exclude such evidence.

The current paradigm does not effectuate the purpose of rape shield laws. The holdings in Young, Garcia, and Jovanovic show that Rules 401 and 403 are not sufficient to bar this type of evidence. A bright line rule is needed. Only by recharacterizing fantasies and dreams as sexual predisposition, rather than sexual behavior, will this type of evidence be excluded under the current rule.

\section{CONCLUSION}

Rape shield laws were enacted as a response to the chastity requirement in traditional rape law and generally prohibit admission of evidence of the victim's prior sexual behavior and sexual predisposition.

315. In civil cases, under Federal Rule of Evidence 412(b)(2), the court may admit evidence of sexual behavior or sexual predisposition if its probative value substantially outweighs the danger of harm to the victim and of unfair prejudice to any party. This exception is problematic and should be reevaluated. As discussed earlier, the sexual predisposition category includes evidence that is not actually sexual predisposition, such as dress and thoughts, but has the potential to invade a woman's privacy and may have a sexual connotation for the factfinder. By allowing the admission of sexual predisposition evidence in civil cases under a balancing test, the court has discretion to admit such evidence. This Article, however, focuses on the admissibility of sexual fantasies and dreams in criminal cases. 
But the consent exception is commonly used. Because the consent exception allows evidence of sexual behavior, and the 1994 Amendment Advisory Committee Notes define sexual behavior to include fantasies and dreams, evidence of a victim's fantasies and dreams may be admissible to prove consent. The assumption underlying admissibility, that women's sexual thoughts make the fact of consent more likely, relies on stereotypes of women's sexuality. And as a result of those stereotypes, the consequence may be the admission and consideration of women's thoughts that should be excluded.

In 1976, Judge Patricia Boyle testified in front of the House Committee considering the creation of Rule 412. Judge Boyle asked: "Do we recognize the right of women to make free and private choices about their own sexual lives or not?"316 The answer is still no. The admissibility of women's sexual fantasies and dreams evidences an ongoing chastity requirement related to rape prosecution and an appropriation of women's thoughts to diminish her legal rights.

316. Hearings, supra note 38, at 81 (statement of J. Patricia Boyle). 